Working Paper 9314

\title{
ACCOUNTING FOR EARNINGS INEQUALITY IN A DIVERSE WORK FORCE
}

by Mark E. Schweitzer

Mark E. Schweitzer is an economist at the Federal Reserve Bank of Cleveland. The author gratefully acknowledges the advice and support of his dissertation committee: Trudy Cameron, Bruce Fallick, David Lewin, Dan Mitchell, and Finis Welch. He also thanks workshop participants at UCLA, Texas A\&M, Case Western Reserve University, and the Federal Reserve Banks of Cleveland and Dallas.

Working papers of the Federal Reserve Bank of Cleveland are preliminary materials circulated to stimulate discussion and critical comment. The views stated herein are those of the author and not necessarily those of the Federal Reserve Bank of Cleveland or of the Board of Governors of the Federal Reserve System.

December 1993 


\begin{abstract}
Groups that are often treated separately in studies of earnings inequality -- women and minorities -- are included in a general decomposition of sources of such disparity among fulltime/full-year labor force participants. In order to consider several possible sources of earnings inequality, a new decomposition is developed that allows semilog earnings models to be decomposed into inequality factors defined by regression coefficients. Simultaneous estimation of inequality factors is justified if correlations between the effects of factors or between factors and the earnings of subgroups exist. Results show that incorporating the covariances between earnings factors and the earnings of subgroups is necessary for an accurate picture of the sources of earnings inequality.

The new decomposition confirms that with the complete labor force included, education remains the largest observable factor in the rise of U.S. earnings inequality in the 1980s. The decomposition also indicates that industry wage differentials have played a contributing role. A large decline in race- and sex-related earnings inequality hides factors capable of explaining the rise in earnings inequality. Finally, a surprising amount of the change in measured inequality is traced to shifts in the supply of workers with given characteristics rather than to shifts in relative earnings.
\end{abstract}




\section{Introduction}

Research to date has been unable to identify statistically the variables that explain the rise in earnings inequality during the 1980s. In order to limit the possible sources of confounding differences, most researchers have limited their focus to a single, well-defined demographic group, usually white males. ${ }^{1}$ Others have compared the inequality trends of a variety of demographic groups. ${ }^{2}$ Previous research on the sources of earnings inequality has also generally been limited to analyzing one source, such as industry or education wage differentials, in isolation from other possible causes. ${ }^{3}$ The residual, or within-group, portion of inequality is repeatedly identified as the decomposition term most associated with the recent rise in earnings inequality. However, the ubiquity of this conclusion may result from the limited flexibility of the commonly applied inequality decompositions, rather than from any weakness in the theoretical explanations.

A brief review of three prominent hypotheses and the approaches taken in the literature reveals that earnings disparity could have risen due to any combination of these explanations and that interactions between the effects may have been important. The leading hypotheses are labor demand shifts due to either the changing industrial structure of employment or skill-biased technological change, and labor supply shifts due to changes in the composition of the work force.

Shifts in the industrial structure of employment appear a priori to be a viable source of rising earnings inequality. ${ }^{4}$ Harrison, Tilly, and Bluestone (1986) argue that the trend toward less manufacturing employment is particularly important. Related arguments for the effects of trade or deunionization also seem to rely on shifts of either wages or employment levels in the affected industries. The analytical response to this hypothesis has been to apply subgroup decompositions to wages by industry. Studies of this type have concluded that the level and rise of earnings

\footnotetext{
1 Juhn, Murphy, and Pierce (1993) and Bound and Johnson (1992) are prominent examples.

2 For example, see Karoly (1992) and Henle and Ryscavage (1980).

3 This is made clear in Levy and Murnane's (1992) literature review, in which potential sources of inequality are considered separately and with little overlap in the cited references.

4 See Plunkert (1990) for a description of the recent change in industry employment levels and Kutscher and Personick (1986) for a longer-term perspective.
} 
inequality appear primarily within industry, bringing into question explanations based on industryrelative wage rates. ${ }^{5}$

A skill-biased technology shift throughout the U.S. economy is also a possible source of earnings inequality, as evidenced by the growing importance of education for all ages of workers. The rise of education earnings differentials was well documented by Murphy and Welch (1988) and has long been acknowledged as an important determinant of pay disparity (see Mincer [1958]). Researchers examining the role of skill prices on earnings inequality have primarily used subgroup decompositions based on age/education categories. ${ }^{6}$ In contrast, Juhn, Murphy, and Pierce (1993) apply an earnings regression with education and experience variables to decompose sources of inequality for male full-time/full-year workers. They find that growing inequality is primarily associated with expanding residuals and returns to education. They then argue that growth in the residuals reflects growth in observed skill differentials (as measured by education levels) and thus can be considered returns to unobserved skill.

Shifts in the composition of the labor force are also a plausible source of earnings inequality. Important changes include the growing percentage of women and minorities working full time, shifts in regional employment patterns, and the aging of the baby-boom generation. Furthermore, the relative wages of these demographic groups have also changed. Possible sources of earnings inequality are not limited to simple shifts in these factors, but could include complex interactions between characteristics, such as educational upgrading by young members of a given race/sex group. Generally, researchers have abstracted from the shifting composition of the labor force by analyzing a single, well-defined group in terms of a subgroup decomposition on another characteristic. The weaknesses of this approach are twofold: First, significant labor supply shifts may not be replicated in each demographic group. Second, demographic groups do not necessarily supply the same skills to the market or concentrate in similar industries.

\footnotetext{
5 For example, see Grubb and Wilson (1989) and Juhn, Murphy, and Pierce (1993).

6 Karoly (1990) and Burtless (1990) both find that education/age categories explain a reasonably constant share of inequality as measured by the variance of log wages and Theil's $T$, respectively.
} 
This paper applies a general model of earnings that encompasses a broad set of variables simultaneously in order to describe sources of earnings inequality. To analyze general earnings factors, the model accounts for industry, education, experience, region, race, and sex differences in weekly pay. Wage differentials for all worker characteristics are adjusted annually in response to shifts in the demand for, or the supply of, workers possessing particular traits.

In order to quantify the model's estimates in terms of proportions of earnings inequality, the paper develops a new decomposition strategy. The estimated coefficients of the model are used to calculate the explained and residual portions of the variance of log wages. The explained portion of earnings inequality is further decomposed into portions explained by categories of variables. These decompositions follow Shorrocks' (1982) decomposition rule for income components, which allows factors to augment or diminish inequality depending on their correlations with other income factors.

The general conclusion of the work presented here is that covariances between inequality factors and groups of workers are important for understanding the recent rise in earnings inequality: Focusing on a single group or factor in isolation may misstate the roles of inequality sources. Specifically, I show that 1) identifiable factors (particularly education) exist that are large enough to account for the recent rise in earnings inequality, 2) industry affiliation and wage differentials are associated with increasing inequality, 3) earnings differences by race and sex are a rapidly declining source of inequality, and 4) shifts in the composition of the work force are a significant factor in rising inequality. While some of the factors estimated here have been studied before, this analysis clarifies their relative roles in a unified framework and establishes that much of the rise in earnings inequality since 1972 stems not from shifting rates of return, but from variations in the composition of the full-time/full-year work force.

The remainder of the paper is organized into five sections. Section II demonstrates the theoretical need to account for earnings factors simultaneously. Section III derives the estimated earnings component decomposition used throughout, and section IV applies this decomposition to a single-equation earnings model. Section $V$ then applies the same decomposition technique to 
fully independent models of earnings by race/sex groups in order to identify sources of inequality connected to a worker's demographic group. Section VI summarizes and concludes. ${ }^{7}$

\section{Complications Implied by a Simple Model of Earnings}

The treatment of earnings inequality in this paper follows the approach of Mincer's (1958) seminal work on human capital and the distribution of personal income. Mincer stressed that inequality due to human-capital differences -- a fundamental source of earnings inequality -should be separated from other sources of disparity. The result of differences in human capital investment can be summarized by the classic earnings equation, as developed in Mincer (1974):

$$
\ln W_{i}=\ln W_{0 i}+r S_{i}+b_{1} X_{i}+b_{2} X_{i}^{2}+v_{i}
$$

where $\ln W_{0 \mathrm{i}}$ is the wage for a worker's innate ability, $S_{i}$ is years of schooling, $X_{i}$ is years of experience, and $v_{i}$ includes unobserved individual differences. Equation (1) is extended below to provide a better fit with the actual experience profile, as suggested by Murphy and Welch (1990).

An important extension of Mincer's framework is to allow workers to gain returns for working in their current industry. While a variety of models support industry-specific returns, the simplest explanation is that workers gain industry-specific training while working in a particular business. This is the logical extension of job-specific human capital (Oi [1962]) to industries. Several alternative models that result in industry wage differentials have been developed, but the data source used for this analysis does not allow those hypotheses to be distinguished. ${ }^{8}$ Following the interindustry wage differential literature, the relevant industry effect is the portion of industry differences remaining after human capital differences and other demographic factors have been accounted for.

\footnotetext{
${ }^{7}$ The construction of the dataset, which largely follows Juhn, Murphy, and Pierce's "committed worker" restrictions, is described in appendix 1.

${ }^{8}$ See Murphy and Topel (1987) for compensating differentials, Krueger and Summers (1987) for efficiency wages, and Gibbons and Katz (1989) for unobserved ability.
} 
Additional demographic factors that can substantially affect an individual's earnings are race, ${ }^{9}$ sex, ${ }^{10}$ and location. ${ }^{11}$ Again, a variety of explanations regarding the role of these variables are possible. A simple but limiting means of accounting for these effects is to assume that the differences are constant across characteristics and to model them with dummy variables. The earnings equation, after accounting for industry and demographic effects, becomes

$$
\ln W_{i}=\ln W_{0 i}+b_{1} S_{i}+b_{2} X_{i}+b_{3} D_{i}^{\text {ind }}+b_{4} D_{i}^{\text {oth }}+v_{i}
$$

where $S_{i}$ represents a vector of schooling-level indicators, $X_{1}$ is a vector of quadratic experience terms, $\mathbf{D}_{i}^{\text {ind }}$ represents industry-specific effects, and $\mathbf{D}_{i}^{\text {oth }}$ represents demographic effects. In the estimation, the rates of return for the various earnings factors are allowed to change from year to year. Thus, the value and distribution of these skills and other factors are allowed to vary with shifts in labor supply and demand.

The implications of this model for mean earnings are well known; however, its implications for earnings inequality have been applied only infrequently in the recent surge of inequality literature. ${ }^{12}$ Consider a scenario of increasing returns to a single factor -- education, for example. The standard decomposition of inequality by subgroups makes a simple comparison of mean earnings by industry and concludes that inequality increases. In terms of equation (2), the range of vector $b_{1}$ is increased. This raises the variance of the term $b_{1} S_{i}$, but the effect of increasing the range of $b_{1}$ on the variance of earnings also depends on the signs of the covariances.

$$
\frac{\partial \operatorname{var}\left(\ln W_{i}\right)}{\partial \operatorname{range}\left(\mathbf{b}_{1}\right)}=\frac{\partial \operatorname{var}\left(\mathbf{b}_{1} \mathbf{S}_{i}\right)}{\partial \operatorname{range}\left(\mathbf{b}_{1}\right)}+2 \frac{\partial \operatorname{cov}\left(\mathbf{b}_{1} \mathbf{S}_{i}, \mathbf{b}_{2} \mathbf{X}_{i}\right)}{\partial \operatorname{range}\left(\mathbf{b}_{1}\right)}+\cdots+2 \frac{\partial \operatorname{cov}\left(\mathbf{b}_{1} \mathbf{S}_{j}, \mathbf{v}_{i}\right)}{\partial \operatorname{range}\left(\mathbf{b}_{1}\right)} .
$$

\footnotetext{
9 Welch (1990) presents a recent example of the role of race in earnings. O'Neill (1990) is an excellent summary of the black/white wage gap since 1940 .

10 Smith and Ward (1989) and Fuchs (1989) are excellent references on the continuing role of gender in pay inequality.

11 See Eberts (1989) for a recent look at regional wage differentials.

12 Smith and Welch (1979) did recognize the importance of covariances between explanatory variables in an analysis of race differences in earnings inequality.
} 
Only the first and last terms of this derivative may be signed: The first is positive and the last (the covariance with the error term) is always zero by ordinary least squares (OLS).

Empirically, these covariances are a substantial and statistically significant portion of total wage variation, as indicated by the correlations in table 1 . These correlations are for a regression of individual log wages on four of the variable categories discussed throughout this paper: experience, education, industry, and region. In addition to being generally significant, these correlations may also change over time, as a cursory comparison of the 1972 and 1990 results indicates. Individual returns to education appear to be especially correlated with two other recognized earnings factors: experience and industry. This is not surprising, since education levels are higher for younger cohorts, and education is clearly associated with one's industry choice.

Table 1. Correlations between Regression Components

\begin{tabular}{c|cccc}
\hline \hline 1972 & Experience & Education & Industry & Region \\
\hline Experience & 1.0 & & & \\
& $(0.00)$ & & & \\
Education & -0.1738 & 1.0 & & \\
& $(0.0001)$ & $(0.00)$ & 1.0 & \\
Industry & 0.0721 & -0.0894 & $(0.00)$ & 1.0 \\
& $(0.0001)$ & $(0.0001)$ & 0.0527 & Region \\
Region & 0.0020 & 0.0405 & $(0.0001)$ & \\
& $(0.6947)$ & $(0.0001)$ & Industry & \\
\hline \hline Experience & 1.0 & Education & & \\
& $(0.00)$ & & & \\
Education & -0.1595 & 1.0 & & 1.0 \\
& $(0.0001)$ & $(0.00)$ & 1.0 & $(0.00)$ \\
Industry & 0.0928 & -0.1204 & $(0.00)$ & \\
& $(0.0001)$ & $(0.0001)$ & 0.0234 & \\
Region & 0.0051 & 0.0360 & $(0.0001)$ & \\
& $(0.2574)$ & $(0.0001)$ & & \\
\hline
\end{tabular}

Note: Figures in parentheses are probability values for the null hypothesis that the correlations are zero.

Neglecting the covariances among the explanatory variables affects the interpretation of the impact of industry wage differentials on earnings inequality. For example, Freeman (1991) argues that the loss of labor union premiums for low-skilled workers has exacerbated earnings inequality. 
Standard subgroup decompositions would be inappropriate without including other observed determinants of industry wage differentials, as they would indicate only the effect of union wage differentials. Freeman's point is that inequality is lower due to a negative covariance between union effects and skill factors. ${ }^{13}$ An inequality decomposition should account for this negative covariance, thereby reducing the earnings inequality associated with union wage differentials. Without direct observation of union status, union effects can be viewed as a component of $\mathbf{b}_{3} \mathbf{D}_{i}^{\text {ind }}$, and the argument continues for industry premiums. Accounting for covariances can be justified similarly for most factors considered in the earnings inequality literature.

\section{Inequality Decomposition bv Estimated Earnings Components}

This paper proposes an alternative inequality decomposition that utilizes our understanding of the sources of earnings differences. The decomposition uses estimates from standard semilog earnings models to separate earnings into additive components. These components can then be evaluated as separate earnings factors. This approach offers several advantages: First, the decomposition can be based on models that have long been accepted by labor economists as reasonably accurate representations of individual earnings. Second, inequality can be speedily decomposed into a large number of categories. Third, inequality can be decomposed according to both discrete and continuous variables. Finally, the models can be evaluated using standard econometric techniques.

\section{Factor Decomposition}

Factor decompositions address different sources of income (for example, family members' incomes in a study of family income inequality), rather than differences between groups of income recipients. Shorrocks (1982) proves that the common, summary inequality measures imply specific factor decompositions when certain basic conditions are met. Unfortunately, the decompositions derived from these rules are fundamentally non-unique. Shorrocks does derive a

13 Freeman avoids this criticism by not performing an explicit inequality decomposition. Instead, he applies shift/share analysis to regression estimates after controlling for education. 
set of natural decompositions, which I argue below are appropriate for this analysis on the basis of their properties. I focus on the variances as an inequality measure in this discussion, because the variance of $\log$ wages $(\mathrm{LV})$ fits with the assumption of log-normal residuals maintained in most human-capital-based models of earnings. Other inequality measures can be similarly decomposed, but the LV is most transparently related to earnings regressions. ${ }^{14}$

Shorrocks' natural decompositions are based on the weighting given to income by the inequality measure. A natural decomposition is derived by finding the specification of the inequality measure that separates inequality into the weight given to a level of income times the individual's income. For the variance, the separation is

$$
\sigma^{2}(Y)=\frac{1}{n} \sum_{i=1}^{N}\left(Y_{i}-\mu\right)^{2}=\sum_{i=1}^{N} \frac{\left(Y_{i}-\mu\right)}{n} Y_{i}-\mu \sum_{i=1}^{N} \frac{Y_{i}}{n}+\mu^{2}=\sum_{i=1}^{N} \frac{\left(Y_{i}-\mu\right)}{n} Y_{i}
$$

The fraction in the final term of equation (4) is the weight applied to the income level $\mathrm{Y}_{\mathrm{i}}$. The weighting term is based on the distance of an individual's income from the mean. This weight defines the natural decomposition.

If $Y_{i}$ is actually the sum of several component incomes, let $Y_{i}=\Sigma Y_{i}^{k}$, where $k$ identifies the income component. Substituting in this summation results in a simple formula for the natural decomposition of the variance in terms of income components:

$$
\begin{aligned}
\sigma^{2}(Y) & =\sum_{i=1}^{N} \frac{\left(Y_{i}-\mu\right)}{n} \sum_{k=1}^{K} Y_{i}^{k}=\sum_{k=1}^{K} \sum_{i=1}^{N} \frac{\left(Y_{i}-\mu\right)}{n} Y_{i}^{k} \\
& =\sum_{k=1}^{K} \operatorname{cov}\left(Y_{k}, Y\right) \equiv \sum_{k=1}^{K} S_{k}^{*}\left(\sigma^{2}\right)
\end{aligned}
$$

14 See Shorrocks (1982). 
Equation (5) shows that this substitution can be simplified to components that are the covariance of the income components and total incomes. The term $S_{k}^{*}\left(\sigma^{2}\right)$ follows Shorrocks' notation for the $\mathrm{k}$-th earnings component decomposition term of the variance $\left(\sigma^{2}\right)$.

\section{Why the Natural Decomposition is Natural}

Shorrocks is unable to find a set of basic assumptions that limit the decompositions to the natural ones. The other decompositions that satisfy his assumptions are any with a linearly homogenous perturbation of the weights derived in equation (5). For Shorrocks, there is no apparent reason to favor any one of these perturbations. To use the natural decompositions, one must assume that the weights applied to income in the basic inequality measure are appropriate for the factor components of decomposed earnings.

A more practical approach to choosing a weighting scheme is to see whether the weights have acceptable implications. The implications of the weights on the variance are readily derivable. If the covariances between wage components are zero, then the decomposition terms $S_{\mathrm{k}}^{*}\left(\sigma^{2}\right)$ sum to $\sigma^{2}$. Otherwise, the decomposition rules implicitly take half the factor interactions and assign them to the respective factors. This implication follows from the fact that

$$
\begin{aligned}
S_{k}^{*}\left(\sigma^{2}\right) & =\operatorname{cov}\left(Y^{k}, Y\right)=\operatorname{var}\left(Y^{k}\right)+\operatorname{cov}\left(Y^{-k}, Y^{k}\right) \\
& =\operatorname{var}\left(Y^{k}\right)+\underset{j \neq k}{\sum} \operatorname{cov}\left(Y^{j}, Y^{k}\right),
\end{aligned}
$$

where $\mathrm{Y}^{-\mathrm{k}}$ represents the sum of all factors other than the $\mathrm{k}$-th. The variance of $\mathrm{Y}$, as the sum of $\mathrm{K}$ random variables, would have the interaction terms $\left[\operatorname{cov}\left(\mathrm{Y}^{\mathrm{j}}, \mathrm{Y}^{\mathrm{k}}\right)\right]$ entered doubly. This result makes clear that the decomposition terms of the natural earnings component represent a sensible, intuitive decomposition of the variation. Although this is only a simple manipulation of basic statistics, it would not hold if other weights were used in the decompositions, because with different weights, $S_{k}^{*}\left(\sigma^{2}\right)$ would not equal $\operatorname{cov}\left(Y^{k}, Y\right)$. 
Additionally, the factor component decomposition is identical to the subgroup decomposition when the factors are defined by a regression on dummy variables that identify group membership. Consider a population that can be divided into $\mathrm{N}$ subgroups. Standard coding of the dummy variables results in an $\mathbf{X}$ matrix of

$$
X=\left(\begin{array}{ccccc}
\mathrm{i}_{1} & 0 & 0 & \ldots & 0 \\
\mathrm{i}_{2} & \mathrm{i}_{2} & 0 & & 0 \\
\mathrm{i}_{3} & 0 & \mathrm{i}_{3} & & 0 \\
\vdots & & & . & \vdots \\
\mathrm{i}_{\mathrm{N}} & 0 & \ldots & \mathrm{i}_{\mathrm{N}}
\end{array}\right)
$$

where $i_{j}$ represents vectors of ones of length $n_{j}$, which is the number of members in group $j^{15}$ This $\mathrm{X}$ matrix excludes the first group from the dummy variables in order to avoid linear dependence with the intercept. Regression of a vector $\mathbf{Y}=\left(\mathrm{y}_{\mathrm{i}}\right)$ on $\mathbf{X}$ results in coefficients of $\boldsymbol{\beta}$ and predictions of $\mathbf{X} \beta$ :

$$
\beta=\left(\begin{array}{c}
\bar{y}_{1} \\
\bar{y}_{2}-\bar{y}_{1} \\
\vdots \\
\bar{y}_{n}-\bar{y}_{1}
\end{array}\right) \quad \text { and } \quad X \beta=\left(\begin{array}{c}
\bar{y}_{1} \\
\bar{y}_{2} \\
\vdots \\
\bar{y}_{n}
\end{array}\right)
$$

where $\overline{\mathbf{y}}_{\mathbf{j}}$ is a vector of the $\mathrm{j}$-th group mean. Note that this regression is just another way to calculate the group means.

Treating $\mathbf{X} \boldsymbol{\beta}$ and $\mathbf{Y}-\mathbf{X} \boldsymbol{\beta}$ as factors of the total (Y) and applying the formula for factor decomposition of the variance (equation [5]) results in a standard variance decomposition by subgroups:

15 The estimations reported later in the paper are based on regressions in which the dummy variables are effects coded. With effects coding, the coefficients express the difference between group k's mean and all groups' mean wages. The results reported herein hold for both standard dummy variable coding and effects coding, as long as the dummy variables serve as a complete set of group-specific intercepts. 


$$
\begin{aligned}
\operatorname{cov}(X \beta, Y) & =\sum_{i=1}^{N}\left(\frac{1}{N} \bar{y}_{j(i)} y_{i}-E\left(\bar{y}_{j(i)}\right) \overline{\bar{y}}\right) \\
& =\sum_{j=1}^{J}\left(\frac{1}{N} \bar{y}_{j} \sum_{i \in j} y_{i}\right)-\overline{\bar{y}}^{2} \\
& =\sum_{j=1}^{J} h_{j}\left(\frac{2}{y_{j}}-\overline{\bar{y}}^{2}\right) .
\end{aligned}
$$

If $\mathbf{Y}$ is wages measured in logs, then the final term of equation (6) is the between-group term of the subgroup decomposition of the LV. The within-group portion is $\operatorname{simply} \operatorname{var}(\mathbf{Y})-\operatorname{cov}(\mathbf{X} \beta, \mathbf{Y})$. These results again follow from choosing the natural decomposition weights. This implies that natural decomposition weights are the appropriate weights for comparisons to the subgroup decompositions that dominate the literature.

Shorrocks develops the variance only for expository purposes and does not discuss the LV. This is because it does not satisfy the principle of transfers -- a criticism that has been shown by Creedy (1977) to be irrelevant within the ranges of income or earnings seen in developed economies. ${ }^{16}$ The LV does offer the clear advantage of being related to the human-capital modeling tradition, however. The models of human capital that follow Mincer's approach assume that the errors of wage equations are lognormally distributed and that the factors determining wages enter multiplicatively. The factor components decomposition makes explicit the relationship between decomposing the LV and human-capital-based wage estimation.

\section{Generalized Factor Components}

Applying the factor components decomposition to a more general earnings model requires incorporating both continuous and qualitative variables. It is difficult to use a group-based

16 The principle of transfers requires the inequality measure to increase whenever income is transferred from a poorer to a richer person. 
decomposition on continuous variables, because they must be split into categorical variables that may not accurately describe the relationship. However, no difficulty arises when applying the factor components decomposition. Consider a regression where $\mathbf{X}_{1}$ is a matrix of either qualitative or cardinal data and $\mathbf{X}_{2}$ is a matrix comprising a set of dummy variables:

$$
\mathbf{Y}=\mathbf{X}_{1} \beta_{1}+\mathbf{X}_{2} \beta_{2}+\mathbf{u}
$$

A standard result of multiple regression shows that the OLS estimates of $\beta_{2}$ are estimates of the effects of $\mathbf{X}_{2}$ on $\mathbf{Y}$ after the effects of $\mathbf{X}_{1}$ have been partialed out:

$$
\beta_{2}=\left(\mathbf{X}_{2}^{\prime} \mathbf{M}_{1} \mathbf{X}_{2}\right)^{-1} \mathbf{X}_{2}^{\prime} \mathbf{M}_{1} \mathbf{Y}
$$

where $\mathbf{M}_{1}=\mathbf{I}-\mathbf{X}_{1}\left(\mathbf{X}_{1}^{\prime} \mathbf{X}_{1}\right)^{-1} \mathbf{X}_{1}^{\prime}$. Then the factor components for the dummy variables $\left(\mathbf{X}_{2} \boldsymbol{\beta}_{2}\right)$ are still means, but the means after the effects of the other variables have been removed:

$$
\mathbf{X}_{2} \beta_{2}=\left(\begin{array}{c}
\overline{\widetilde{\mathbf{y}}}_{1} \\
\overline{\widetilde{\mathbf{y}}}_{2} \\
\vdots \\
\widetilde{\widetilde{\mathbf{y}}}_{\mathrm{n}}
\end{array}\right)
$$

The same is also true for the continuous variables, except that the prediction from a continuous variable is not a group mean. By construction, $X_{1} \beta_{1}, X_{2} \beta_{2}$, and $u$ are additive factors in earnings on which earnings inequality can be decomposed according to equation (2).

The ability to consider simultaneously a variety of factors affecting earnings is one of the major advantages of this approach. Another is that the results are for a given factor after the effects of other variables have been removed. The value of this can be seen by considering an example. Wages in many service industries have maintained or improved their position relative to manufacturing wages. ${ }^{17}$ This could be due to service industries paying more of an industry differential, or it could be due to their hiring more skilled workers (in particular, more educated

17 Average hourly earnings for manufacturing workers fell from $\$ 8.33$ in 1970 to $\$ 8.07$ in 1990 (1982 dollars). Over the same period, service industry wages rose from $\$ 6.99$ to $\$ 7.39$ (see 1992 Statistical Abstract of the United States, table 650, p. 410). 
workers). In either case, controlling for the level of education and experience in the service work force would identify lower relative service industry wages. A traditional subgroup decomposition on industries would miss the shift in wage differentials that is hidden by skill upgrading in the service sector.

An earnings model can be broken into factors as long as the sum of those factors equals total earnings. This allows the researcher to evaluate any linear hypotheses that can be specified in an earnings equation as sources of earnings inequality. Nested linear models can be evaluated for their relative power in explaining earnings inequality. Ultimately, however, the decomposition of earnings into estimated components is limited only by the flexibility of the models.

\section{Inequality Decomoositions Based on a Single-Equation Earnings Model}

The single-equation earnings model (equation [2]) implies that the differences in wages seen among demographic groups are attributable to a group-specific intercept and to differences in the distribution of skills between groups. That is, returns to human capital and other factors are equal regardless of one's race or sex. This section identifies inequality factors on the basis of that assumption. The possibility that the assumption might not hold will be considered in section IV.

\section{Explained and Residual Earnings Inequality}

Table 2 shows the degree to which the model is able to predict observed inequality differences. This is the simplest decomposition possible, but it provides information on how completely the model represents the data. The percentage of predicted inequality explained in a single-equation model is equal to the $\mathrm{R}^{2}$ of a regression. Thus, earnings models should not be expected to describe all (or even most) of the variation in earnings when a plethora of important but unobserved individual differences are not taken into account. Nonetheless, this model does remarkably well. For 1975 , it predicted an inequality level of 0.1382 , which is 46.29 percent of all variation in log earnings. The model predictions of the LV level in the economy are relatively stable at around 0.14 . However, inequality due to the residual rises throughout the period; thus, the model explains a declining share of the LV of wages. 
Table 2. Predicted/Residual Decomposition of the LV

\begin{tabular}{c|c|cc|c}
\hline \hline Year & LV of Wages & $\begin{array}{c}\text { LV of Model } \\
\text { Predictions }\end{array}$ & $\begin{array}{c}\text { LV of Model } \\
\text { Residuals }\end{array}$ & $\begin{array}{c}\text { Percentage } \\
\text { Explained }\end{array}$ \\
\hline 1972 & 0.3173 & 0.1395 & 0.1778 & $43.96 \%$ \\
1973 & 0.3218 & 0.1449 & 0.1769 & 45.03 \\
1974 & 0.3222 & 0.1386 & 0.1836 & 43.03 \\
1975 & 0.2985 & 0.1382 & 0.1603 & 46.29 \\
1976 & 0.3025 & 0.1373 & 0.1652 & 45.39 \\
1977 & 0.3083 & 0.1381 & 0.1702 & 44.79 \\
1978 & 0.3087 & 0.1337 & 0.1751 & 43.30 \\
1979 & 0.3055 & 0.1311 & 0.1745 & 42.90 \\
1980 & 0.3068 & 0.1306 & 0.1762 & 42.56 \\
1981 & 0.3132 & 0.1300 & 0.1832 & 41.51 \\
1982 & 0.3252 & 0.1350 & 0.1902 & 41.51 \\
1983 & 0.3267 & 0.1363 & 0.1904 & 41.72 \\
1984 & 0.3384 & 0.1403 & 0.1981 & 41.46 \\
1985 & 0.3480 & 0.1462 & 0.2018 & 42.02 \\
1986 & 0.3559 & 0.1493 & 0.2067 & 41.94 \\
1987 & 0.3571 & 0.1449 & 0.2122 & 40.57 \\
1988 & 0.3431 & 0.1422 & 0.2008 & 41.46 \\
1989 & 0.3468 & 0.1444 & 0.2023 & 41.65 \\
1990 & 0.3433 & 0.1403 & 0.2030 & 40.86 \\
\hline
\end{tabular}

The total, explained, and residual inequality trends listed in table 2 are shown graphically in figure 1. Clearly, the rise in earnings inequality is driven by increases in the earnings equation residuals. In addition, the shift in imputation techniques used by the Census Bureau appears to be concentrated in the residuals, which fall from their trend in 1975. At this level of decomposition, the trend in the observed portion of earnings inequality is maintained through the switch in techniques, while the residual portion is dramatically altered.

Although the model includes industry, region, race, and sex variables, applying a technique similar to that of Juhn, Murphy, and Pierce (1993) indicates that earnings inequality is still rising primarily in the unobservables. Without the techniques developed in section III, this would be the limit of the analysis on this model. Now, however, the explained inequality can be broken down into more narrowly defined categories of variables in order to address more specific sources of wage inequality. 
Figure 1. Total, Explained, and Residual Inequality

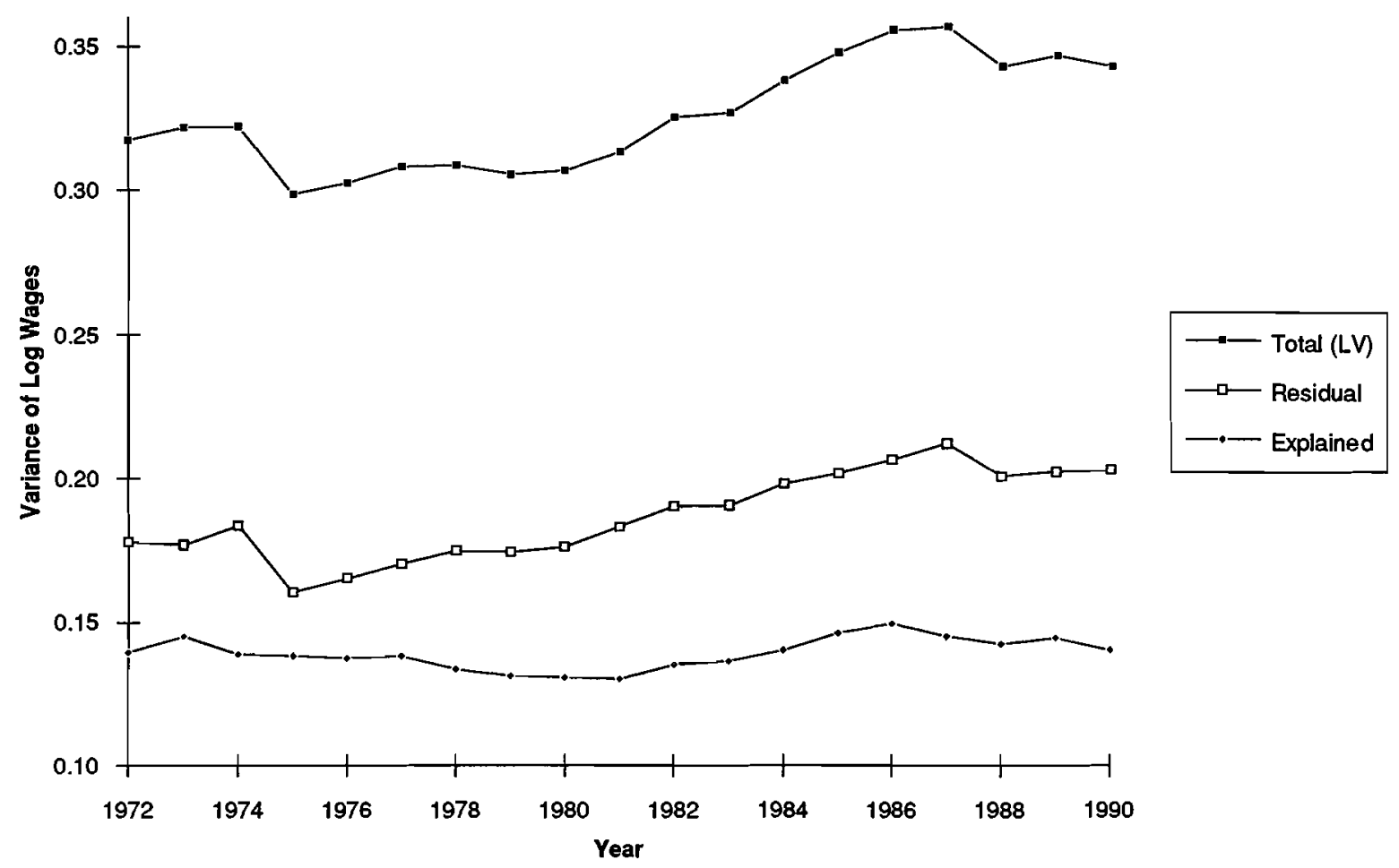

Factor Shares of Explained Earnings Inequality

This model was designed to ascertain the relative roles of industry effects, human-capital factors, and labor supply shifts in explaining earnings inequality. This earnings-component-based method of decomposition can be easily applied to any collection of the model's set of variables. While the overall model's explained inequality did not change dramatically from 1972 to 1990 , the effects of certain worker characteristics rose or fell rapidly. The results of a decomposition of the model's estimates into categories are shown in table 3. The experience group includes the quartic terms of potential experience. The education group includes the dummy variables for high school dropout, some college, college graduation, and graduate schooling. The race/sex group includes the dummy variables for white females, minority females, and minority males. The industry group includes the 38 industry dummy variables. The region group includes dummy variables for the 
nine census regions. The estimated wage effects $(\mathbf{X} \beta)$ are calculated for each group of variables from annual regressions, which are detailed in appendix 2 for selected years.

Table 3. Estimated Earnings Component of the LV of Wages

\begin{tabular}{c|c|ccccc}
\hline \hline Year & $\begin{array}{c}\text { LV of } \\
\text { Wages }\end{array}$ & $\begin{array}{c}\text { LV of } \\
\text { Exp. }\end{array}$ & $\begin{array}{c}\text { LV of } \\
\text { Educ. }\end{array}$ & $\begin{array}{c}\text { LV of } \\
\text { Race/Sex }\end{array}$ & $\begin{array}{c}\text { LV of } \\
\text { Industry }\end{array}$ & $\begin{array}{c}\text { LV of } \\
\text { Region }\end{array}$ \\
\hline 1972 & 0.3173 & 0.0226 & 0.0385 & 0.0564 & 0.0161 & 0.0060 \\
1973 & 0.3218 & 0.0254 & 0.0385 & 0.0604 & 0.0151 & 0.0055 \\
1974 & 0.3222 & 0.0272 & 0.0365 & 0.0548 & 0.0158 & 0.0043 \\
1975 & 0.2985 & 0.0246 & 0.0427 & 0.0475 & 0.0189 & 0.0044 \\
1976 & 0.3025 & 0.0263 & 0.0400 & 0.0461 & 0.0202 & 0.0048 \\
1977 & 0.3083 & 0.0275 & 0.0402 & 0.0469 & 0.0195 & 0.0041 \\
1978 & 0.3087 & 0.0250 & 0.0389 & 0.0467 & 0.0192 & 0.0039 \\
1979 & 0.3055 & 0.0242 & 0.0392 & 0.0442 & 0.0199 & 0.0036 \\
1980 & 0.3068 & 0.0242 & 0.0409 & 0.0415 & 0.0207 & 0.0033 \\
1981 & 0.3132 & 0.0228 & 0.0430 & 0.0405 & 0.0209 & 0.0028 \\
1982 & 0.3252 & 0.0235 & 0.0500 & 0.0367 & 0.0226 & 0.0022 \\
1983 & 0.3267 & 0.0252 & 0.0527 & 0.0337 & 0.0221 & 0.0027 \\
1984 & 0.3384 & 0.0261 & 0.0556 & 0.0342 & 0.0218 & 0.0027 \\
1985 & 0.3480 & 0.0261 & 0.0603 & 0.0324 & 0.0240 & 0.0034 \\
1986 & 0.3559 & 0.0263 & 0.0631 & 0.0315 & 0.0242 & 0.0041 \\
1987 & 0.3571 & 0.0240 & 0.0624 & 0.0311 & 0.0229 & 0.0044 \\
1988 & 0.3431 & 0.0221 & 0.0612 & 0.0287 & 0.0247 & 0.0056 \\
1989 & 0.3468 & 0.0216 & 0.0675 & 0.0261 & 0.0231 & 0.0061 \\
1990 & 0.3433 & 0.0214 & 0.0685 & 0.0225 & 0.0226 & 0.0053 \\
\hline
\end{tabular}

The experience group represents about 15 to 20 percent of the explained variation, reaching a peak of $0.0275 \mathrm{LV}$ (19.9 percent of explained inequality) in 1977 and a low of $0.0214 \mathrm{LV}$ (15.3 percent) in 1990. As a factor explaining earnings inequality, experience is substantial but relatively stable. This is confirmed by figure 2 , which compares the relative trends of all five factors. Recalling that the experience variables are based on years of potential work experience $(=$ age - education -6$)$, the lack of a substantial rise in this component indicates a minor role for cohort effects. The entrance of the baby-boom generation does not greatly alter earnings inequality through the age/earnings profile.

sducation variables explain a much larger share of the variance of log earnings. The explained variance accounted for by education dummies rises from a low of $0.0365 \mathrm{LV}$ (26.4 percent of explained inequality) in 1973 to a high of $0.0685 \mathrm{LV}$ (48.8 percent) in 1990 . The 
explanatory power of education variables increases fairly consistently throughout the period, despite the fact that the estimated college differentials actually declined during most of the 1970s. (See appendix 2 for the regression estimates for selected years.) The rise in education's importance in this period could be due to the other differentials (high school dropout, some college, or graduate school) or to shifts in the labor supply. This question will be pursued below.

The race and sex variables likewise play a significant role in explaining earnings inequality. They start with a peak explanatory power of 0.0604 (41.6 percent of explained earnings inequality) in 1973 , but by 1990 account for only 0.0225 LV (16.1 percent). This dramatic fall, which is spread consistently over the period, has not been noted in previous studies because most researchers either have considered only men or have treated men and women as if they participated in different labor markets. The massive influx of women into the full-time work force, along with their sharply declining conditional wage differentials, has generally been ignored. The relative wages of minorities also improved over time in this sample.

The share of industry variables in explained inequality is not as large or as steeply trended as either the education or race/sex shares. However, the effect of industry wage differentials rises from $0.0151 \mathrm{LV}$ (10.4 percent of explained earnings inequality) in 1973 to $0.0247 \mathrm{LV}$ (17.4 percent) in 1988, with most of the growth occurring in the period leading up to 1982 . The share of inequality represented by the industry factor does little to bolster theories positing that the increase in overall inequality is mainly the result of shifts in industrial composition. However, unlike in previous studies, the trend in the industry component is noticeably upward.

Regional differences play a consistently small role in earnings inequality. A low of 0.0022 (1.6 percent) is reached in 1982. By 1989 , regions' share of explained earnings inequality had returned to 4.4 percent, or $0.0061 \mathrm{LV}$. This pattern coincides with the reversal in long-run regional convergence in the early 1980s, as reported by Eberts (1989). However, the effects of regional wage differentials on overall earnings inequality has been slight, as Grubb and Wilson (1989) noted for regional subgroup decompositions. 


\section{Figure 2. Trends in Inequality Factors}

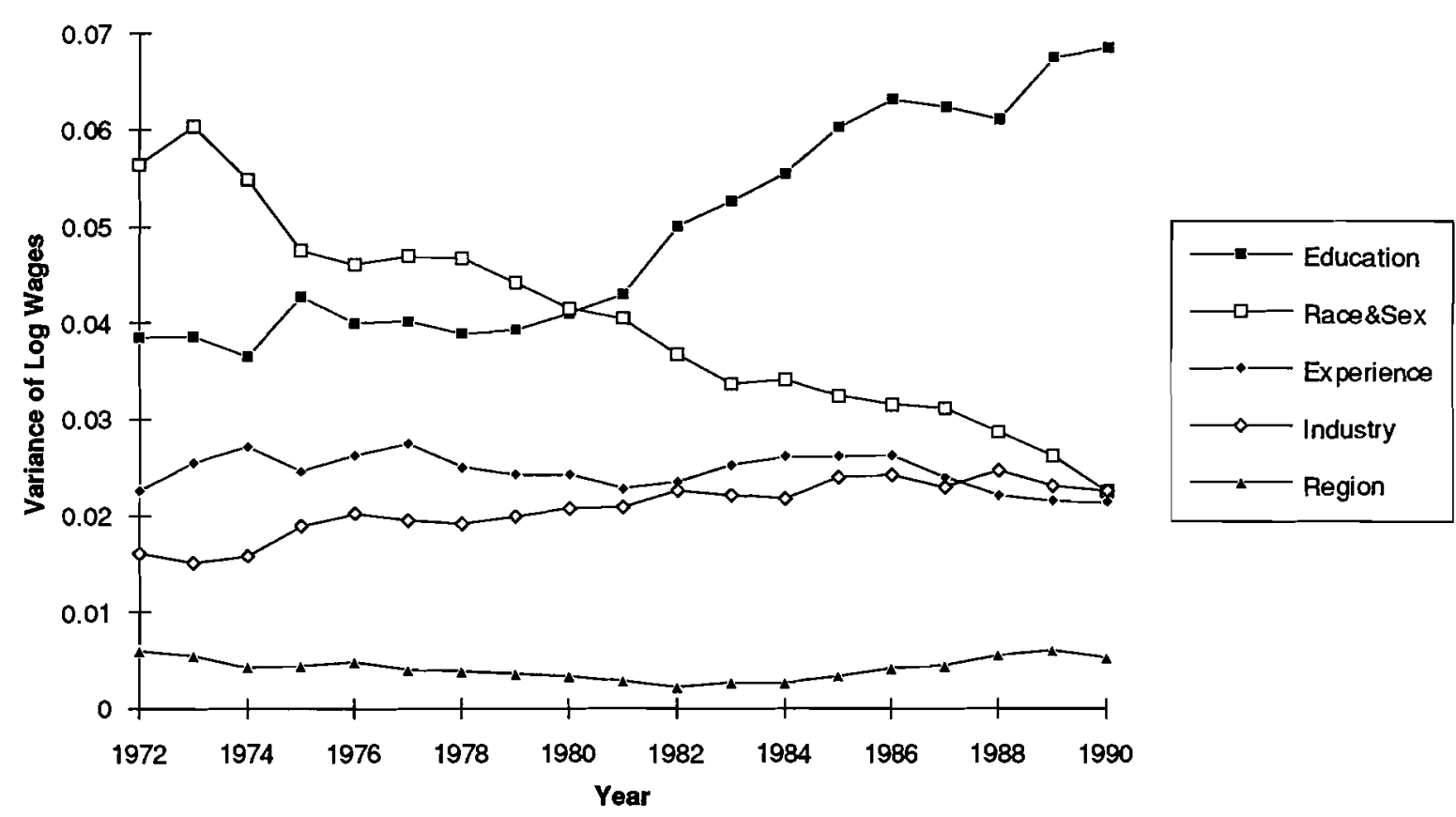

Simple calculations from table 3 indicate that trends in some of these factors are large enough to have caused the change in overall inequality over the sample period. Inequality due to education differences rose 116.7 percent as much as overall earnings inequality from 1972 to 1990. This implies that if all factors other than education (including the residuals) were held constant over the period, earnings inequality would have risen 16.7 percent more than it actually did. Moreover, from 1972 to 1992 , the industry factor rose 25.3 percent as much as overall inequality.

These increases are more than canceled out by the drop in race and sex differences. Raceand sex-related inequality declined at a rate equal to 131.2 percent of the increase in overall earnings inequality. In addition, experience- and region-related inequality over the full period fell only slightly when compared to growth in the overall measure. This means that while the rise in total inequality is not "explained" by the standard model, the model does identify factors 
(education and industry) that, if not offset by falling race- and sex-related differences, would have caused a greater increase in earnings disparity than seen in the United States since 1972.

\section{Model Comparisons}

Table 4 compares the estimated earnings components to their related subgroup decompositions. The subgroup decompositions for any factor can be evaluated as the earnings components for a nested model in which the effects of all other explanatory variables are unrelated to wages or are orthogonal to the factor of interest. This follows from equation (6), which shows that the earnings component decomposition is identical to the subgroup decomposition when the only explanatory variables are a complete set of classifying dummy variables.

The race/sex-group decomposition associates about 20 percent more inequality with these two characteristics than does the earnings component decomposition. The difference peaks in 1980 at 23.8 percent. The subgroup decomposition also estimates a declining role for race/sex groups in explaining earnings inequality. However, not accounting for workers' education, experience, and industry results in increasingly larger overestimates of between-group inequality up to 1980 , slowing the pre-1980 decline and speeding the post-1980 decline.

Education is treated as a categorical variable in the earnings component decomposition, making it comparable to a subgroup decomposition on completed levels of schooling. The effects are similar in the two decompositions, indicating that education's role in earnings inequality is largely independent of the other explanatory variables. In fact, there is a tendency for the subgroup decompositions to understate the role of education in earnings inequality. This difference peaks in 1979 at 18.1 percent of the earnings component estimate. As educationrelated inequality rises rapidly in the $1980 \mathrm{~s}$, the difference between the two estimates declines, indicating the growing independence of the estimated education differentials and the other factors, but steepening the rise reported by the subgroup decomposition. 
Table 4. Comparisons to Subgroup Decompositions

\begin{tabular}{c|cc|cc|cc}
\hline & \multicolumn{2}{|c|}{ Race/Sex Groups } & \multicolumn{2}{c|}{ Education Groups } & \multicolumn{2}{c}{ Industries } \\
\hline Year & $\begin{array}{c}\text { Subgroup } \\
\text { Decomposition }\end{array}$ & Difference & $\begin{array}{c}\text { Subgroup } \\
\text { Decomposition }\end{array}$ & Difference & $\begin{array}{c}\text { Subgroup } \\
\text { Decomposition }\end{array}$ & Difference \\
& & & & & \\
1972 & 0.0675 & $19.7 \%$ & 0.0336 & $-12.7 \%$ & 0.0318 & $97.6 \%$ \\
1973 & 0.0711 & $17.9 \%$ & 0.0343 & $-11.1 \%$ & 0.0297 & $96.5 \%$ \\
1974 & 0.0657 & $19.8 \%$ & 0.0321 & $-12.2 \%$ & 0.0299 & $88.6 \%$ \\
1975 & 0.0593 & $24.8 \%$ & 0.0364 & $-14.8 \%$ & 0.0347 & $83.4 \%$ \\
1976 & 0.0568 & $23.3 \%$ & 0.0334 & $-16.5 \%$ & 0.0365 & $81.2 \%$ \\
1977 & 0.0575 & $22.5 \%$ & 0.0335 & $-16.5 \%$ & 0.0350 & $79.9 \%$ \\
1978 & 0.0572 & $22.4 \%$ & 0.0323 & $-17.1 \%$ & 0.0336 & $75.2 \%$ \\
1979 & 0.0542 & $22.7 \%$ & 0.0321 & $-18.1 \%$ & 0.0328 & $65.0 \%$ \\
1980 & 0.0514 & $23.8 \%$ & 0.0341 & $-16.6 \%$ & 0.0333 & $61.1 \%$ \\
1981 & 0.0500 & $23.5 \%$ & 0.0364 & $-15.4 \%$ & 0.0342 & $63.6 \%$ \\
1982 & 0.0453 & $23.4 \%$ & 0.0424 & $-15.3 \%$ & 0.0362 & $59.9 \%$ \\
1983 & 0.0411 & $22.0 \%$ & 0.0452 & $-14.3 \%$ & 0.0369 & $67.1 \%$ \\
1984 & 0.0410 & $19.9 \%$ & 0.0488 & $-12.3 \%$ & 0.0371 & $70.6 \%$ \\
1985 & 0.0393 & $21.1 \%$ & 0.0528 & $-12.6 \%$ & 0.0393 & $63.8 \%$ \\
1986 & 0.0378 & $20.0 \%$ & 0.0567 & $-10.2 \%$ & 0.0406 & $67.9 \%$ \\
1987 & 0.0362 & $16.3 \%$ & 0.0576 & $-7.6 \%$ & 0.0391 & $70.5 \%$ \\
1988 & 0.0335 & $17.0 \%$ & 0.0561 & $-8.4 \%$ & 0.0405 & $63.7 \%$ \\
1989 & 0.0307 & $17.3 \%$ & 0.0625 & $-7.5 \%$ & 0.0392 & $69.7 \%$ \\
1990 & 0.0257 & $14.3 \%$ & 0.0642 & $-6.3 \%$ & 0.0383 & $69.3 \%$ \\
\hline
\end{tabular}

The subgroup decomposition by industry estimates much higher between-industry inequality than the estimated earnings decomposition would support. Initially, it is nearly double the estimate of industry-related inequality from the model. This is not surprising, since education and sex are highly correlated with a person's choice of industry and have been shown to be important explanations of earnings inequality. Thus, using the subgroup decomposition to evaluate shifts in the distribution of industry employment commingles the effects of education and other variables by overestimating the effects of industry wage differentials and distorting the trend over time.

The differences shown in table 4 for these two decompositions indicate that there are important correlations between inequality factors that must be accounted for. To be fair, most previous research has applied subgroup decompositions to at least a few factors simultaneously. Unfortunately, the number of factors has been limited by the need to interpret the effects of particular variables. 


\section{Fixed-Return Comparisons}

A valuable extension of the preceding analysis is to separate the effects of population shifts from the effects of changes in the returns to worker characteristics. Basic shift/share analysis, in which the population having given characteristics is adjusted in order to isolate population effects, cannot be applied to this decomposition because the correlations between individual characteristics are critical. Shift/share analysis implicitly assumes that the nature of the correlations stays constant.

A related approach is to contrast the explained inequality level under the restriction that the estimated coefficients are constant in all years. Here, the restricted case is referred to as fixedreturn estimates because the coefficients represent the amount a hypothetical average individual is paid for having that characteristic. This comparison can isolate the effects of changes in rates of return paid to earnings factors from the changing distribution of those factors. Much as in shift/share analysis, in addition to the returns and quantities terms, there is covariance between the two terms that will be assumed to be zero. This allows the simple separation

$$
S_{k}^{*}\left(\sigma^{2}\right)=\operatorname{cov}\left(\mathbf{X}_{k} \beta_{k}, Y_{i}\right)=\operatorname{cov}\left(\mathbf{X}_{k} \widetilde{\beta}_{k}, Y_{i}\right)+\operatorname{cov}\left(\mathbf{X}_{k}\left(\beta_{k}-\widetilde{\beta}_{k}\right), Y_{j}\right)
$$

where $\widetilde{\beta}_{\mathrm{k}}$ represents any desired value of the coefficient vector for the $\mathrm{k}$-th factor.

Table 5 a shows the restricted beta inequality components over time, and table 5 b shows the difference between the restricted and unrestricted cases. The difference between the two estimates equals the final term in equation (7), which is an inequality-weighted measure of the difference between coefficients. A positive value in table $5 \mathrm{~b}$ indicates that allowing the coefficients to vary increases earnings inequality; a negative number implies reduced earnings inequality when coefficients are allowed to change. 
Table 5a. Effect of Holding Returns Constant

\begin{tabular}{c|c|ccccc}
\hline \hline & \multicolumn{5}{|c}{ Levels of Explained Inequality If Factor Returns Are Held Constant } \\
\hline Year & Total Expl. & Experience & Education & Race/Sex & Industry & Region \\
\hline 1972 & 0.1395 & 0.0226 & 0.0385 & 0.0564 & 0.0161 & 0.0060 \\
1973 & 0.1429 & 0.0243 & 0.0393 & 0.0579 & 0.0156 & 0.0058 \\
1974 & 0.1403 & 0.0254 & 0.0383 & 0.0561 & 0.0154 & 0.0051 \\
1975 & 0.1411 & 0.0247 & 0.0406 & 0.0537 & 0.0168 & 0.0053 \\
1976 & 0.1403 & 0.0262 & 0.0392 & 0.0526 & 0.0174 & 0.0050 \\
1977 & 0.1406 & 0.0264 & 0.0392 & 0.0531 & 0.0174 & 0.0045 \\
1978 & 0.1380 & 0.0255 & 0.0385 & 0.0532 & 0.0166 & 0.0042 \\
1979 & 0.1359 & 0.0250 & 0.0384 & 0.0520 & 0.0165 & 0.0040 \\
1980 & 0.1356 & 0.0246 & 0.0397 & 0.0507 & 0.0166 & 0.0039 \\
1981 & 0.1352 & 0.0235 & 0.0413 & 0.0501 & 0.0167 & 0.0037 \\
1982 & 0.1371 & 0.0234 & 0.0450 & 0.0478 & 0.0174 & 0.0035 \\
1983 & 0.1375 & 0.0237 & 0.0466 & 0.0456 & 0.0176 & 0.0039 \\
1984 & 0.1394 & 0.0239 & 0.0485 & 0.0456 & 0.0174 & 0.0039 \\
1985 & 0.1412 & 0.0239 & 0.0504 & 0.0447 & 0.0181 & 0.0042 \\
1986 & 0.1437 & 0.0239 & 0.0525 & 0.0440 & 0.0187 & 0.0047 \\
1987 & 0.1414 & 0.0227 & 0.0530 & 0.0430 & 0.0181 & 0.0046 \\
1988 & 0.1388 & 0.0215 & 0.0524 & 0.0414 & 0.0185 & 0.0051 \\
1989 & 0.1390 & 0.0212 & 0.0554 & 0.0396 & 0.0177 & 0.0050 \\
1990 & 0.1352 & 0.0209 & 0.0561 & 0.0363 & 0.0171 & 0.0049 \\
\hline
\end{tabular}


Table 5b. Effect of Holding Returns Constant

\begin{tabular}{c|c|ccccc}
\hline \hline & \multicolumn{6}{|c}{ Increase in Factor Estimates with Flexible Returns } \\
\hline Year & Total Expl. & Experience & Education & Race/Sex & Industry & Region \\
\hline 1972 & 0.0000 & 0.0000 & 0.0000 & 0.0000 & 0.0000 & 0.0000 \\
1973 & 0.0020 & 0.0011 & -0.0008 & 0.0024 & -0.0005 & -0.0003 \\
1974 & -0.0016 & 0.0018 & -0.0017 & -0.0013 & 0.0004 & -0.0008 \\
1975 & -0.0029 & -0.0001 & 0.0021 & -0.0062 & 0.0022 & -0.0009 \\
1976 & -0.0029 & 0.0001 & 0.0008 & -0.0065 & 0.0028 & -0.0001 \\
1977 & -0.0025 & 0.0010 & 0.0010 & -0.0062 & 0.0021 & -0.0005 \\
1978 & -0.0043 & -0.0005 & 0.0004 & -0.0065 & 0.0026 & -0.0003 \\
1979 & -0.0049 & -0.0008 & 0.0008 & -0.0078 & 0.0033 & -0.0004 \\
1980 & -0.0050 & -0.0004 & 0.0012 & -0.0092 & 0.0041 & -0.0006 \\
1981 & -0.0052 & -0.0007 & 0.0017 & -0.0096 & 0.0042 & -0.0008 \\
1982 & -0.0021 & 0.0001 & 0.0050 & -0.0111 & 0.0052 & -0.0013 \\
1983 & -0.0012 & 0.0015 & 0.0061 & -0.0120 & 0.0045 & -0.0013 \\
1984 & 0.0009 & 0.0022 & 0.0070 & -0.0115 & 0.0044 & -0.0012 \\
1985 & 0.0050 & 0.0023 & 0.0099 & -0.0122 & 0.0059 & -0.0008 \\
1986 & 0.0055 & 0.0024 & 0.0106 & -0.0124 & 0.0055 & -0.0006 \\
1987 & 0.0035 & 0.0013 & 0.0094 & -0.0119 & 0.0049 & -0.0002 \\
1988 & 0.0034 & 0.0007 & 0.0088 & -0.0127 & 0.0062 & 0.0005 \\
1989 & 0.0054 & 0.0003 & 0.0121 & -0.0135 & 0.0054 & 0.0011 \\
1990 & 0.0050 & 0.0005 & 0.0124 & -0.0138 & 0.0055 & 0.0004 \\
\hline
\end{tabular}

If all returns to worker characteristics were held at their 1972 levels, the ability to explain earnings inequality would have been slightly lower in 1990 than in 1973 . Referring to table 5 b, with constrained rates of return, earnings inequality would have been higher with the 1972 levels of returns from 1974 to 1983 . This reversal is the result of sharply rising returns to education in the 1980s. The largest differences, and therefore the largest return-related shifts, occurred in the education-, race/sex-, and industry-related components.

Education-related inequality increased throughout the period due to changes in both the number of workers with particular education levels and the returns to higher education. In fact, 58.3 percent of the increase in education-related inequality would have occurred without any change in the returns to education. Shifts in the returns and in the percentage of the sample at different education levels over the period are shown in table 6 . Changes in both the estimated 
returns and the sample shares are large, but without applying equation (7), it would be difficult to measure their relative role in inequality terms. Tables $5 \mathrm{a}$ and $5 \mathrm{~b}$ convert these shifts into their relative effects on earnings inequality.

Table 6. Education Returns and Work-Force Shares

\begin{tabular}{c|rccc}
\hline \hline & 1972 & \multicolumn{4}{c}{1978} & 1984 & 1990 \\
\hline Level & \multicolumn{4}{c}{ Estimated Value of Education Differentials } \\
\hline H.S. Dropout & $-16.47 \%$ & $-20.36 \%$ & $-22.07 \%$ & $-23.07 \%$ \\
Some College & $14.20 \%$ & $13.56 \%$ & $16.00 \%$ & $19.51 \%$ \\
College Grad. & $53.74 \%$ & $47.48 \%$ & $55.85 \%$ & $62.84 \%$ \\
Post-Graduate & $74.91 \%$ & $74.16 \%$ & $91.02 \%$ & $97.23 \%$ \\
\hline \hline Frequency & \multicolumn{4}{|c}{ Percentage of Full-time/Full-year Work Force } \\
\hline H.S. Dropout & $28.42 \%$ & $21.50 \%$ & $16.17 \%$ & $13.66 \%$ \\
H.S. Graduate & $41.77 \%$ & $41.97 \%$ & $41.75 \%$ & $40.58 \%$ \\
Some College & $13.84 \%$ & $17.48 \%$ & $19.20 \%$ & $20.82 \%$ \\
College Grad. & $11.76 \%$ & $13.77 \%$ & $16.04 \%$ & $17.36 \%$ \\
Post-Graduate & $4.20 \%$ & $5.27 \%$ & $6.84 \%$ & $7.58 \%$ \\
\hline
\end{tabular}

Note: Percentages are in terms of weekly wages evaluated around the intercept. The regression estimates are reported in greater detail in appendix 2.

The declining role of race and sex differences can likewise be traced to both quantity and relative wage effects. If the race/sex wage differentials had not changed during the period, inequality stemming from those factors would have fallen 59.3 percent as much as actually occurred. Table 7 shows that estimated relative wages and work-force shares changed dramatically during this time, however. The surprising fact is that increased participation by women and minorities in the full-time/full-year labor force reduced earnings inequality.

Table 7. Race/Sex-Group Relative Wages and Work-Force Shares

\begin{tabular}{c|rccc}
\hline \hline & 1972 & 1978 & 1984 & 1990 \\
\hline Level & \multicolumn{4}{c}{ Estimated Value of Race/Sex-Group Differentials } \\
\hline White Female & $-36.88 \%$ & $-33.49 \%$ & $-29.10 \%$ & $-24.69 \%$ \\
Minority Female & $-40.76 \%$ & $-35.84 \%$ & $-32.46 \%$ & $-28.25 \%$ \\
Minority Male & $-20.71 \%$ & $-15.75 \%$ & $-16.87 \%$ & $-13.72 \%$ \\
\hline \hline Frequency & \multicolumn{4}{c}{ Percentage of Full-time/Full-year Work Force } \\
\hline White Male & $61.20 \%$ & $56.76 \%$ & $53.27 \%$ & $51.15 \%$ \\
White Female & $28.58 \%$ & $31.72 \%$ & $34.24 \%$ & $35.77 \%$ \\
Minority Female & $4.23 \%$ & $5.17 \%$ & $6.10 \%$ & $6.45 \%$ \\
Minority Male & $5.99 \%$ & $6.34 \%$ & $6.39 \%$ & $6.63 \%$ \\
\hline
\end{tabular}

Note: Percentages are in terms of weekly wages evaluated around the intercept. The regression estimates are reported in greater detail in appendix 2. 
The industry component differs from the other results. Tables $5 \mathrm{a}$ and $5 \mathrm{~b}$ show that without shifts in the industry wage differentials, little increase in industry-related earnings inequality would have occurred. Holding the coefficients on the industry dummy variables constant, industry-related inequality would have been only slightly higher (0.0010) in 1990 than in 1973. This is just 15.4 percent of the rise in industry-related earnings inequality, implying that the large-scale shifts of the work force out of manufacturing did not directly increase explained inequality. Instead, growing differentials account for most of industry's direct effect.

Section IV establishes the value of decomposing wages in a manner that allows for factors to interact in a complex manner. The results suggest focusing the analysis on the roles of education levels and race/sex groups in determining earnings inequality. To that end, section $\mathrm{V}$ attempts to better characterize the role of growing gender and racial diversity in the American work force.

\section{Further Accounting for Race/Sex Effects}

While the specification developed in section $\square$ is a standard framework for measuring race and sex earnings differentials, it does not identify detailed sources of the differences. A flexible specification that accounts for these differences by allowing complete variation in rates of return for all factors and for the error term by race/sex group is described in equation (8):

$$
\ln W_{i}=\sum_{C \varepsilon(\text { Race/Sex Groups }\}}\left(\ln W_{0 C}+b_{1 C} S_{i}+b_{2 C} X_{i}+b_{3 C} D_{i}^{\text {ind }}+b_{4 C} D_{i}^{\text {oth }}+v_{i C}\right),
$$

where $\mathrm{C}$ indicates the race/sex group of individual $\mathrm{i}$.

Returns to factors could vary by race or sex for several reasons. Returns to observed factors could differ due to qualities unobserved by the econometrician but observed by market participants. Or, race or sex discrimination could be limited to particular sections of the labor market or restricted to certain factors. One clear source of differences in rates of return by 
race/sex is the differing rates of actual experience for given levels of potential experience observed in the Current Population Survey. Alternatively, differing rates of return could develop as a response to the inability of workers to unbundle their set of skills, as shown by Heckman and Scheinkman (1987). They prove that differences in rates of returns for observed and unobserved skill factors can vary by group if the proportions of skills vary by group when workers are unable to market their skills separately.

Equation (8) shows the more complicated covariance structure to be summarized by the decomposition. This extension alters the interpretation of the factors and allows for comparisons across groups. A change to a single group's rate of return paid to a factor depends on both the covariance structure with that group's other factors and the covariances between that group's and other groups' wages. Repeating the earlier example of an increase in the rate of return to education for workers in group 1 of four race/sex groups, we have

$$
\begin{aligned}
\frac{\partial \operatorname{var}\left(\ln \mathbf{W}_{i}\right)}{\partial \operatorname{range}\left(\mathbf{b}_{1,1}\right)}= & \frac{\partial \operatorname{var}\left(\mathbf{b}_{1,1} \mathbf{S}_{i}\right)}{\partial \operatorname{range}\left(\mathbf{b}_{1,1}\right)}+2 \frac{\partial \operatorname{cov}\left(\mathbf{b}_{1,1} \mathbf{S}_{i}, \mathbf{b}_{2,1} \mathbf{X}_{i}\right)}{\partial \operatorname{range}\left(\mathbf{b}_{1,1}\right)}+\cdots+2 \frac{\partial \operatorname{cov}\left(\mathbf{b}_{1,1} \mathbf{S}_{i}, \mathbf{v}_{i}\right)}{\partial \operatorname{range}\left(\mathbf{b}_{1,1}\right)} \\
& +2 \frac{\operatorname{cov}\left(\mathbf{b}_{1,1} \mathbf{S}_{i}, \ln W_{i \varepsilon(2,3,4}\right)}{\partial \operatorname{range}\left(\mathbf{b}_{1,1}\right)}
\end{aligned}
$$

Equation (9) raises the possibility of factors that could increase earnings inequality within a group and yet reduce population-wide earnings inequality.

Table 8 a shows the levels of inequality associated with the same factors considered in section IV after allowing each race/sex group to earn returns to factors independently. The level of these inequality factors can be either above or below the measured value when the factor payments are constrained to be equal. Equation (10) shows that the sign of the difference depends on the degree that returns accrued to the race/sex groups differ from the general estimates.

$$
S_{k}^{*}\left(\sigma^{2}\right)=\operatorname{cov}\left(X_{k} \beta_{k, C}, Y_{i}\right)=\operatorname{cov}\left(X_{k} \beta_{k}, Y_{i}\right)+\operatorname{cov}\left(X_{k}\left[\beta_{k, C}-\beta_{k}\right], Y_{i}\right)
$$


These differences are shown in table $8 \mathrm{~b}$. Positive values mean that differences in the rates of return by race/sex group for a given factor increase the inequality associated with that factor. In this specification, the race/sex factor is calculated by comparing the intercepts of the independent race/sex-group earnings equations.

Estimating earnings equations with independent coefficients adds somewhat to the amount of variation explained by the model, as would be expected. The increase in explanatory power is slightly more prominent in the early 1970 s than in the late $1980 \mathrm{~s}$, so the amount of predicted earnings inequality actually declines over the period.

Table 8a. Estimated Earnings Components with Independent Race/Sex Groups

\begin{tabular}{c|c|ccccc}
\hline \hline & \multicolumn{5}{|c}{ Levels of Explained Inequality When Factor Returns Differ by Race/Sex Groups } \\
\hline Year & Total Expl. & Experience & Education & Race/Sex & Industry & Region \\
\hline 1972 & 0.1463 & 0.0692 & 0.0358 & 0.0191 & 0.0157 & 0.0065 \\
1973 & 0.1514 & 0.0693 & 0.0372 & 0.0227 & 0.0164 & 0.0058 \\
1974 & 0.1454 & 0.0715 & 0.0342 & 0.0175 & 0.0181 & 0.0041 \\
1975 & 0.1444 & 0.0611 & 0.0403 & 0.0188 & 0.0197 & 0.0044 \\
1976 & 0.1436 & 0.0652 & 0.0380 & 0.0144 & 0.0206 & 0.0054 \\
1977 & 0.1446 & 0.0656 & 0.0367 & 0.0181 & 0.0192 & 0.0049 \\
1978 & 0.1397 & 0.0605 & 0.0357 & 0.0194 & 0.0199 & 0.0042 \\
1979 & 0.1371 & 0.0606 & 0.0357 & 0.0173 & 0.0195 & 0.0040 \\
1980 & 0.1366 & 0.0573 & 0.0379 & 0.0165 & 0.0210 & 0.0039 \\
1981 & 0.1359 & 0.0576 & 0.0403 & 0.0137 & 0.0210 & 0.0034 \\
1982 & 0.1408 & 0.0550 & 0.0475 & 0.0129 & 0.0229 & 0.0026 \\
1983 & 0.1415 & 0.0516 & 0.0506 & 0.0140 & 0.0220 & 0.0032 \\
1984 & 0.1465 & 0.0573 & 0.0527 & 0.0115 & 0.0224 & 0.0027 \\
1985 & 0.1517 & 0.0554 & 0.0589 & 0.0090 & 0.0245 & 0.0038 \\
1986 & 0.1550 & 0.0554 & 0.0611 & 0.0160 & 0.0180 & 0.0045 \\
1987 & 0.1499 & 0.0496 & 0.0605 & 0.0113 & 0.0238 & 0.0047 \\
1988 & 0.1477 & 0.0536 & 0.0583 & 0.0042 & 0.0256 & 0.0060 \\
1989 & 0.1496 & 0.0477 & 0.0644 & 0.0068 & 0.0242 & 0.0064 \\
1990 & 0.1449 & 0.0449 & 0.0660 & 0.0040 & 0.0243 & 0.0057 \\
\hline
\end{tabular}


Table 8b. Estimated Earnings Components with Independent Race/Sex Groups

\begin{tabular}{c|c|ccccc}
\hline \hline & \multicolumn{5}{|c}{ Increase in Factor Estimates When Factor Returns Differ by Race/Sex Groups } \\
\hline Year & Total Expl. & Experience & Education & Race/Sex & Industry & Region \\
\hline 1972 & 0.0068 & 0.0467 & -0.0027 & -0.0373 & -0.0004 & 0.0006 \\
1973 & 0.0065 & 0.0439 & -0.0014 & -0.0376 & 0.0013 & 0.0004 \\
1974 & 0.0067 & 0.0444 & -0.0024 & -0.0374 & 0.0023 & -0.0001 \\
1975 & 0.0062 & 0.0365 & -0.0024 & -0.0287 & 0.0007 & 0.0000 \\
1976 & 0.0063 & 0.0389 & -0.0020 & -0.0317 & 0.0004 & 0.0006 \\
1977 & 0.0065 & 0.0381 & -0.0034 & -0.0288 & -0.0003 & 0.0009 \\
1978 & 0.0060 & 0.0355 & -0.0032 & -0.0274 & 0.0008 & 0.0003 \\
1979 & 0.0060 & 0.0365 & -0.0036 & -0.0269 & -0.0004 & 0.0004 \\
1980 & 0.0060 & 0.0331 & -0.0031 & -0.0250 & 0.0003 & 0.0006 \\
1981 & 0.0059 & 0.0349 & -0.0027 & -0.0268 & 0.0001 & 0.0005 \\
1982 & 0.0058 & 0.0315 & -0.0026 & -0.0238 & 0.0003 & 0.0004 \\
1983 & 0.0052 & 0.0264 & -0.0021 & -0.0196 & -0.0001 & 0.0006 \\
1984 & 0.0063 & 0.0312 & -0.0029 & -0.0226 & 0.0006 & 0.0000 \\
1985 & 0.0054 & 0.0293 & -0.0014 & -0.0234 & 0.0006 & 0.0004 \\
1986 & 0.0058 & 0.0291 & -0.0020 & -0.0155 & -0.0062 & 0.0004 \\
1987 & 0.0050 & 0.0257 & -0.0019 & -0.0199 & 0.0009 & 0.0003 \\
1988 & 0.0054 & 0.0315 & -0.0029 & -0.0244 & 0.0008 & 0.0004 \\
1989 & 0.0051 & 0.0261 & -0.0031 & -0.0193 & 0.0011 & 0.0003 \\
1990 & 0.0046 & 0.0235 & -0.0025 & -0.0186 & 0.0017 & 0.0005 \\
\hline
\end{tabular}

Differences in returns by race/sex groups primarily alter the experience and race/sex components. The race/sex component is consistently lower throughout the period (about onethird the size calculated in the single-equation model) and declines more rapidly (ending at 20 percent of its 1972 value). Most of this difference is picked up by the experience component, which more than doubles its values compared to the results of the single-equation decomposition. It also picks up some of the decline from the single-equation race/sex component, dropping $0.0243 \mathrm{LV}$ from 1972 (71 percent of the decline in the race/sex component in the single-equation decomposition). This indicates that the key factor in race- and sex-related inequality is differences in the rates of return for potential experience. It also shows that these differences are declining rapidly. Inequality falls 12 percent faster in the sum of the experience and race/sex factors than in the race/sex factor in the single-equation model. This difference corresponds to the higher initial inequality predictions of this decomposition. 
Qualitatively, as can be verified in figure 3, only small differences are seen in the education, industry, and region components when factor returns are allowed to vary by race/sex groups. Education continues to be the largest increasing factor in earnings inequality. The change in the education component is 0.0302 , compared with 0.0300 in the basic decomposition. It follows that education is still capable of explaining the growth in earnings inequality, but is now typically about 8 percent smaller. The industry factor is generally somewhat larger and increases at a rate 32 percent faster than in the basic decomposition. Regional variation remains a minor component and is not significantly altered.

Figure 3. Estimated Earnings Components with Independent Race/Sex Groups

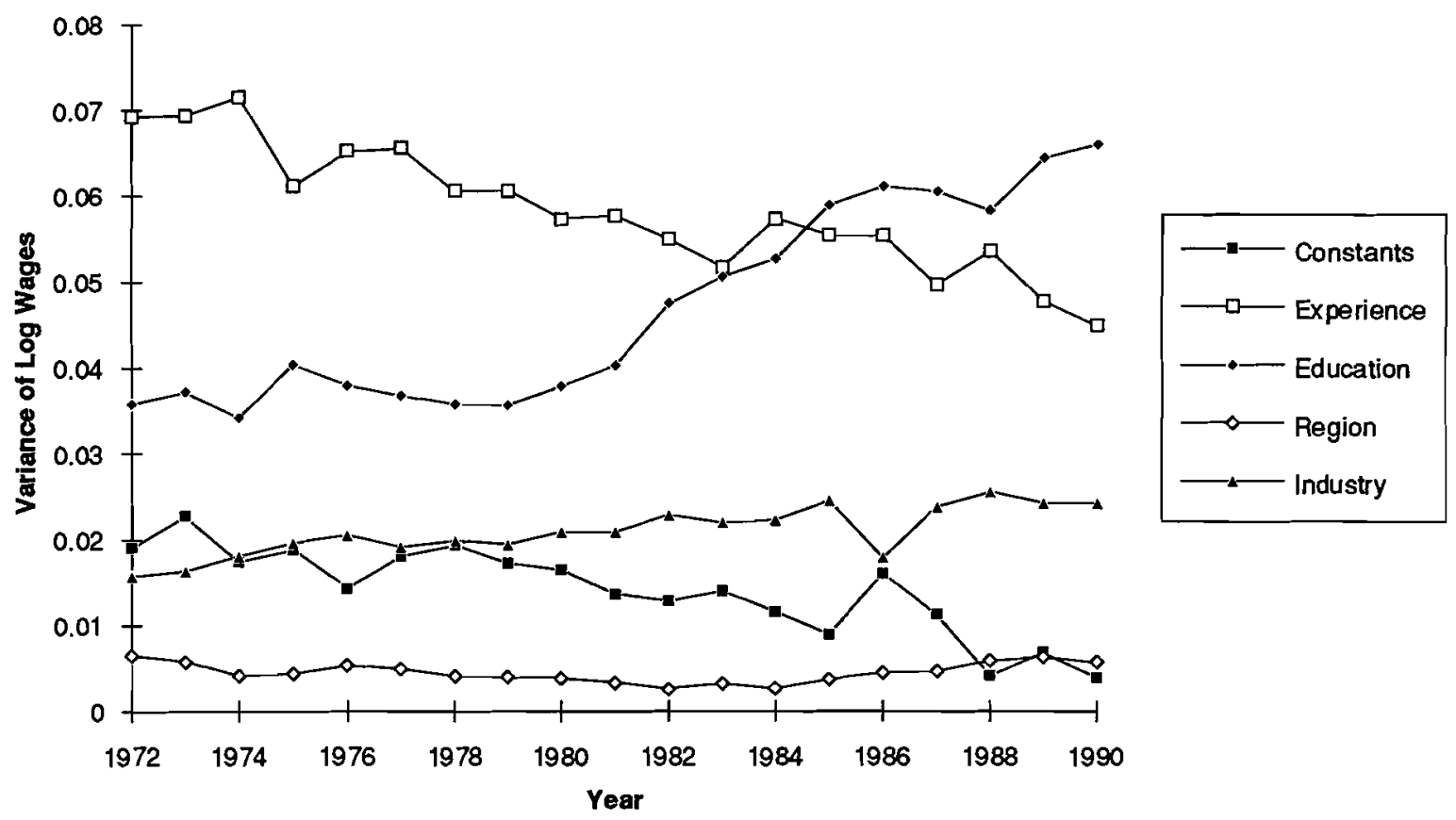

The general conclusions of this decomposition are similar to those of the single-equation model. Education continues to be the most significant rising factor, with industry affiliation playing a supporting role. Again, there is clear evidence of the declining importance of race and sex in earnings inequality, although the effect now appears to be split between those variables and group-specific returns to experience. Applying equation (10), we can conclude that the labor 
market outcomes by race/sex groups for skill factors (education and experience) have varied significantly.

\section{Fixed-Return Comparisons}

In order to better identify the sources of change in this disaggregated model of earnings, the fixed-return analysis is repeated below with each group's returns held at 1972 levels. The results of this decomposition, along with the difference between the fixed- and flexible-return decompositions (table 8), are shown in table 9.

The factors that are not substantially altered when independent race/sex group equations are estimated continue to be similar to the single-equation case with factor returns held constant. Education is even more affected by shifts in the number of workers at various education levels than by shifts in the returns for increases in that component (64 percent of the change would have occurred with no change in returns). The industry component continues to be driven mostly (78 percent) by shifts in industry wage differentials rather than by shifts in industry employment shares. 
Table 9a. Effect of Holding Returns Constant with Independent Race/Sex Groups

\begin{tabular}{c|c|ccccc}
\hline \hline & \multicolumn{5}{|c}{ Levels of Explained Inequality If Factor Returns Are Held Constant } \\
\hline Year & $\begin{array}{c}\text { Total } \\
\text { Explained }\end{array}$ & Experience & Education & Race/Sex & Industry & Region \\
\hline 1972 & 0.1463 & 0.0692 & 0.0358 & 0.0191 & 0.0157 & 0.0065 \\
1973 & 0.1486 & 0.0718 & 0.0364 & 0.0194 & 0.0145 & 0.0063 \\
1974 & 0.1457 & 0.0711 & 0.0356 & 0.0188 & 0.0147 & 0.0056 \\
1975 & 0.1452 & 0.0675 & 0.0380 & 0.0179 & 0.0161 & 0.0057 \\
1976 & 0.1444 & 0.0681 & 0.0368 & 0.0175 & 0.0165 & 0.0056 \\
1977 & 0.1454 & 0.0688 & 0.0368 & 0.0176 & 0.0170 & 0.0052 \\
1978 & 0.1421 & 0.0670 & 0.0365 & 0.0175 & 0.0165 & 0.0047 \\
1979 & 0.1400 & 0.0657 & 0.0367 & 0.0172 & 0.0159 & 0.0045 \\
1980 & 0.1401 & 0.0646 & 0.0379 & 0.0167 & 0.0162 & 0.0047 \\
1981 & 0.1400 & 0.0636 & 0.0394 & 0.0164 & 0.0162 & 0.0043 \\
1982 & 0.1415 & 0.0618 & 0.0434 & 0.0157 & 0.0165 & 0.0041 \\
1983 & 0.1413 & 0.0603 & 0.0451 & 0.0150 & 0.0164 & 0.0045 \\
1984 & 0.1438 & 0.0611 & 0.0470 & 0.0150 & 0.0162 & 0.0045 \\
1985 & 0.1455 & 0.0601 & 0.0491 & 0.0146 & 0.0170 & 0.0048 \\
1986 & 0.1480 & 0.0598 & 0.0512 & 0.0141 & 0.0174 & 0.0054 \\
1987 & 0.1455 & 0.0576 & 0.0517 & 0.0140 & 0.0169 & 0.0053 \\
1988 & 0.1443 & 0.0558 & 0.0513 & 0.0133 & 0.0180 & 0.0059 \\
1989 & 0.1445 & 0.0541 & 0.0544 & 0.0128 & 0.0175 & 0.0057 \\
1990 & 0.1396 & 0.0513 & 0.0551 & 0.0117 & 0.0160 & 0.0054 \\
\hline
\end{tabular}


Table 9b. Effect of Holding Returns Constant with Independent Race/Sex Groups

\begin{tabular}{l|c|ccccc}
\hline \hline & \multicolumn{5}{|c}{ Increase in Factor Estimates with Flexible Returns } \\
\hline Year & $\begin{array}{c}\text { Total } \\
\text { Explained }\end{array}$ & Experience & Education & Race/Sex & Industry & Region \\
\hline 1972 & 0.0000 & 0.0000 & 0.0000 & 0.0000 & 0.0000 & 0.0000 \\
1973 & 0.0029 & -0.0025 & 0.0007 & 0.0033 & 0.0018 & -0.0005 \\
1974 & -0.0003 & 0.0004 & -0.0014 & -0.0013 & 0.0034 & -0.0014 \\
1975 & -0.0009 & -0.0064 & 0.0023 & 0.0009 & 0.0036 & -0.0013 \\
1976 & -0.0009 & -0.0029 & 0.0012 & -0.0031 & 0.0041 & -0.0002 \\
1977 & -0.0008 & -0.0032 & -0.0001 & 0.0005 & 0.0023 & -0.0002 \\
1978 & -0.0024 & -0.0065 & -0.0007 & 0.0019 & 0.0034 & -0.0005 \\
1979 & -0.0029 & -0.0050 & -0.0010 & 0.0000 & 0.0036 & -0.0005 \\
1980 & -0.0035 & -0.0073 & -0.0001 & -0.0002 & 0.0047 & -0.0008 \\
1981 & -0.0041 & -0.0060 & 0.0008 & -0.0027 & 0.0047 & -0.0010 \\
1982 & -0.0008 & -0.0069 & 0.0041 & -0.0029 & 0.0064 & -0.0015 \\
1983 & 0.0002 & -0.0086 & 0.0055 & -0.0010 & 0.0056 & -0.0013 \\
1984 & 0.0027 & -0.0038 & 0.0056 & -0.0034 & 0.0061 & -0.0018 \\
1985 & 0.0062 & -0.0046 & 0.0099 & -0.0055 & 0.0076 & -0.0011 \\
1986 & 0.0070 & -0.0044 & 0.0099 & 0.0019 & 0.0005 & -0.0009 \\
1987 & 0.0044 & -0.0080 & 0.0088 & -0.0028 & 0.0069 & -0.0006 \\
1988 & 0.0034 & -0.0022 & 0.0071 & -0.0091 & 0.0075 & 0.0001 \\
1989 & 0.0050 & -0.0063 & 0.0100 & -0.0060 & 0.0067 & 0.0007 \\
1990 & 0.0053 & -0.0064 & 0.0109 & -0.0078 & 0.0082 & 0.0003 \\
\hline
\end{tabular}

The experience and race/sex components are dramatically altered by the switch in decompositions, and the decomposition terms are also altered under the assumption of constant returns. The change in experience-related inequality is 73 percent when determined without any change in relative returns, whereas race- and sex-related inequality drops off only 49 percent as much. This indicates that a fair amount of the shrinking inequality in the experience factor is traceable to more equal experience levels for women and minorities. Evaluating the two components together for comparison with the single-equation decomposition, I find that 64 percent of the decline would have occurred with no change in returns. This compares to 59 percent for the race/sex component in the single-equation decomposition, meaning that allowing different race/sex-group factor returns raised the amount of the race/sex-related inequality explained by work-force shares rather than by returns. 
One difficulty with experience returns is pinpointing the size and location of the important differences that contribute to earnings inequality. By plotting the full experience-earnings profiles for each of the groups, the scale of the differences can be evaluated at any level of potential experience. Rates of return to experience are evaluated at the characteristic means of the race/sex groups for 1972 and 1990 in figures 4 and 5. First, notice that both figures indicate substantial differences; however, the plots converge noticeably in 1990 compared to 1972 . This convergence explains 36 percent of the decline in experience-related wage inequality indicated in tables $9 \mathrm{a}$ and $9 b$.

\section{Figure 4. 1972 Experience-Earnings Profiles}

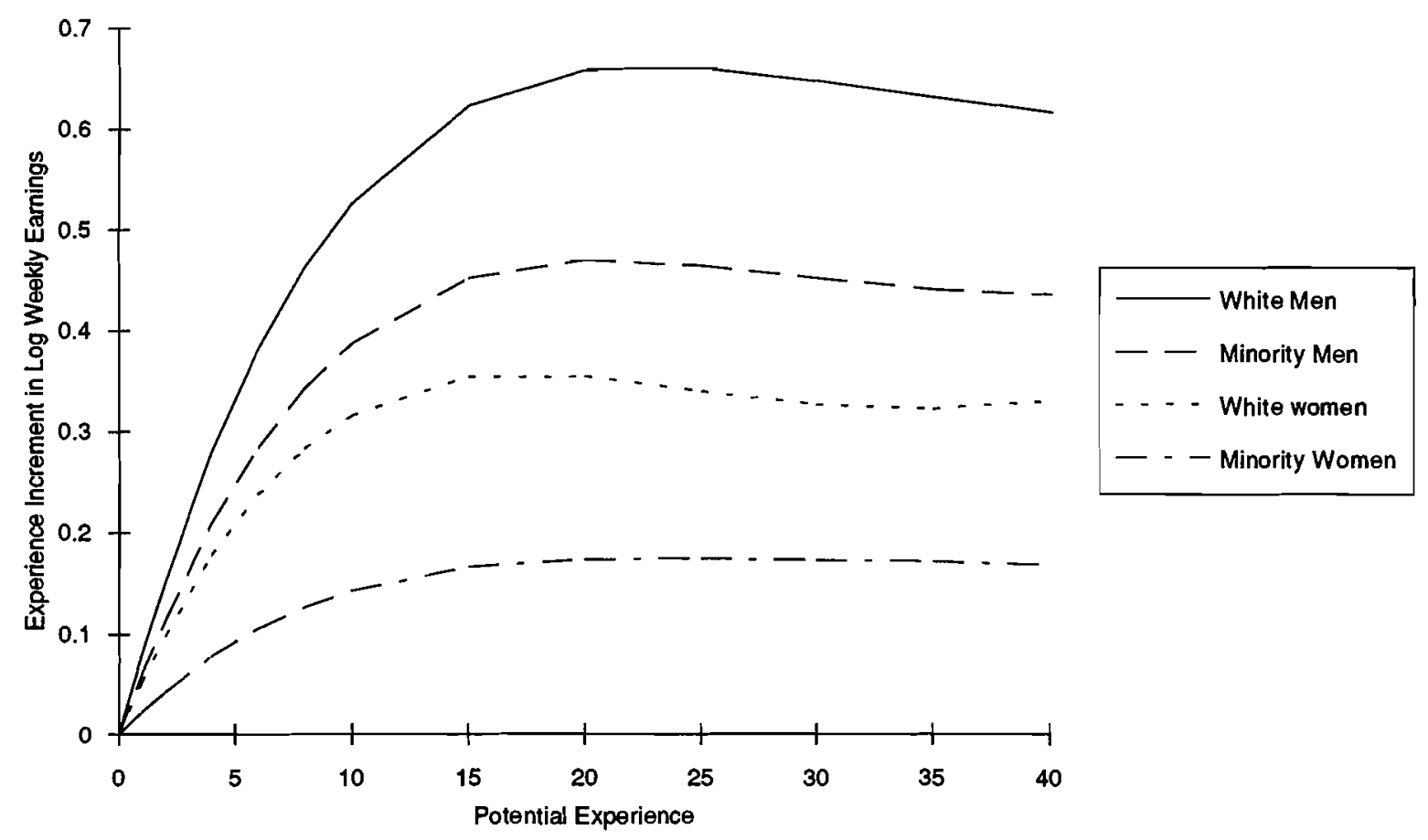




\section{Figure 5. 1990 Experience-Earnings Profiles}

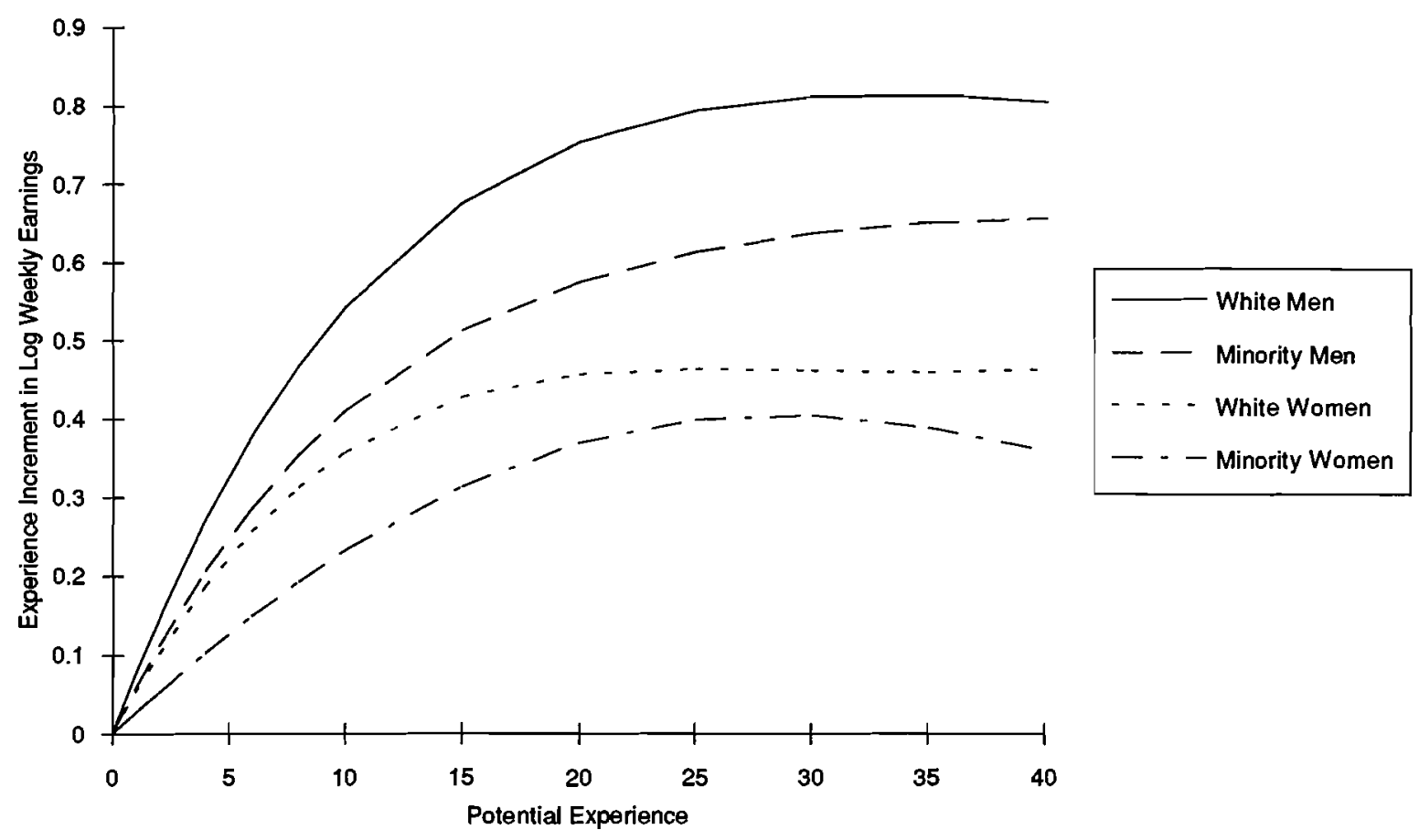

As the factors associated with race and sex (the equation intercepts and experience profiles) become more equitable, education generally becomes more highly rewarded (table 10). With the exception of highly educated minority women, additional education is better rewarded in 1990 for all race/sex groups. Interestingly, education was more steeply rewarded among women than men in 1972 and 1990, indicating that in terms of education differentials, men's wages have shifted toward the steeper profile of women's wages. The impact of these increasing returns on overall wage inequality could be mixed, as growth in higher-education differentials for women could reduce earnings inequality due to their generally lower wages. Nonetheless, these broadly distributed shifts in education returns cause earnings inequality in this decomposition to rise at about the same rate as in the single-equation decomposition. Again, tables $9 \mathrm{a}$ and $9 \mathrm{~b}$ indicate that a large fraction (67 percent) of the overall increase in education-related inequality would have occurred without the shifts in returns to education. This result, when compared with Juhn, Murphy, and Pierce's (1993) finding that supply adjustments were minor for white males, suggests 
that supply adjustment in other demographic groups more significantly altered the trend in inequality.

Table 10. Education Differentials by Race/Sex Group

\begin{tabular}{c|rccc}
\hline \hline & \multicolumn{4}{|c}{ Estimated Value of Education Differentials } \\
\hline 1972 & White Men & Minority Men & White Women & Minority Women \\
\hline H.S. Dropout & $-18.22 \%$ & $-15.99 \%$ & $-11.19 \%$ & $-13.28 \%$ \\
Some College & $14.63 \%$ & $7.29 \%$ & $12.48 \%$ & $9.15 \%$ \\
College Grad. & $50.54 \%$ & $44.52 \%$ & $51.71 \%$ & $72.20 \%$ \\
Post-Graduate & $75.49 \%$ & $77.01 \%$ & $80.16 \%$ & $124.49 \%$ \\
\hline \hline 1990 & White Men & Minority Men & White Women & Minority Women \\
\hline H.S. Dropout & $-25.72 \%$ & $-15.42 \%$ & $-21.42 \%$ & $-15.06 \%$ \\
Some College & $19.01 \%$ & $20.12 \%$ & $18.26 \%$ & $15.47 \%$ \\
College Grad. & $58.69 \%$ & $51.69 \%$ & $65.02 \%$ & $52.29 \%$ \\
Post-Graduate & $89.47 \%$ & $99.58 \%$ & $102.63 \%$ & $102.20 \%$ \\
\hline
\end{tabular}

Note: Percentages are in terms of weekly wages evaluated around the race/sex-group intercept.

\section{Conclusion}

The decomposition technique employed in this paper allows the factors contributing to the recent rise in earnings inequality to be identified in greater detail than was possible with previous models. Earnings components estimated from a standard earnings model describe sources of increasing and decreasing earnings disparity that are large enough to explain the total rise in the measure. In particular, the growing importance of education differences is enough to explain the increase in inequality between 1972 and 1990 . However, the counteracting trend toward decreasing inequality due to race and sex differentials masks the pickup in education-related differences. Both trends are driven by changes in relative pay rates and participation rates. Also hidden by falling race- and sex-related inequality are smaller, but not insubstantial, industry effects. The increase in industry-related inequality is estimated to be 21.9 percent as large as the total growth in inequality. This rise occurred because estimated industry wage differentials have grown, not because of shifts in the industrial composition of the work force.

Allowing the returns to worker characteristics to vary by race/sex group confirms and extends the single-equation model's conclusions. Education is again the primary contributing factor in earnings inequality, supported by growing disparity by industry affiliation. These factors 
rise more than enough to explain the total increase in earnings inequality over the sample period. The model also clarifies the drop in sex- and race-related inequality. The largest factor here is differing rates of return on potential experience by race/sex group. Declines in this factor result primarily not from observed shifts in the experience-earnings profiles, but from changing patterns of experience. The smaller, but still receding, factor described by the intercept terms of the independent equation shows that general differentials between race/sex groups have also assumed a lesser role over time.

One conclusion that can be drawn from both sets of decompositions is that shifts in the composition of the labor force have generally been understated as sources (and reducing elements) of earnings inequality. Regardless of the decomposition, the rise in education-related inequality, which is generally ascribed to rising returns, appears to be more than 50 percent determined by the supply of educated labor. This distinction is accentuated when race/sex groups are statistically allowed to receive differing rates of returns. The growing diversity of the fulltime/full-year work force, extended beyond simple race/sex differentials, has contributed substantially to earnings inequality. Neglecting the participation of a growing fraction of the labor force may have caused previous analyses to focus excessively on shifts in returns rather than in quantities.

This decomposition technique allows identification of the major determinants of earnings inequality: worker education levels and industry affiliation. The scale of change in these factors suggests that the model may be identifying the sources of the increase in earnings inequality, but it does not eliminate the existence of a large and rising residual term. There could be factors embedded in this residual term that explain the overall rise in earnings inequality. This problem exists with any regression failing to explain the majority of the variation in the dependent variable. However, there are a number of reasons why earnings regressions should not be expected to explain most of the variation in wages. Many factors not captured in this regression (motivation, school quality, etc.) are rewarded by the market. These factors are not likely to be identified in any decomposition of earnings inequality. It should, however, be reassuring to know that factors 
predicted to be critical in the growth of earnings inequality are substantial enough to cause the observed rise in this measure. Explanations that rely on these factors as their sources of inequality are more easily defended in this context.

This analysis has not attempted to eliminate any of the competing hypotheses for rising earnings inequality. It has, however, demonstrated that in a complete sample of full-time/full-year labor force participants, the composition of the labor supply plays an important role. The massive shifts in labor supply between 1972 and 1990 (in the form of higher participation rates for women and minorities), along with increases in mean education levels, do not contradict a technological or industrial demand shift. In fact, they strengthen the argument in favor of a demand shift when labor supplies appear to accommodate demand growth, yet returns still rise. These decompositions help to identify the shifts that should be explained. 


\section{References}

Blackburn, M. L. and D. E. Bloom (1987), "The Effects of Technological Change on Earnings and Income Inequality in the United States," in Richard Cyert and David Mowery, eds., The Impact of Technological Change on Employment and Economic Growth. Cambridge, Mass.: Harper and Row, 223-263.

Bluestone, Barry and Bennett Harrison (1986), "The Great American Job Machine: The Proliferation of Low Wage Employment in the U.S. Economy," study prepared for the U.S. Congressional Joint Economic Committee.

Bound, John and George Johnson (1992), "Changes in the Structure of Wages during the 1980's: An Evaluation of Alternative Explanations," American Economic Review, 82(3), 371-392.

Burtless, Gary (1990), "Earnings Inequality over the Business and Demographic Cycles," in Gary Burtless, ed., A Future of Lousy Jobs?, Washington, D.C.: The Brookings Institution, 77-122.

Creedy, John (1977), "The Principle of Transfers and the Variance of the Logarithms," Oxford Bulletin of Economics and Statistics, 39, 152-158.

Eberts, Randall (1989), "Accounting for the Recent Divergence in Regional Wage Differentials," Federal Reserve Bank of Cleveland, Economic Review, 25(3), 14-26.

Freeman, Richard (1991), "How Much Has De-unionization Contributed to the Rise in Male Earnings Inequality?" National Bureau of Economic Research Working Paper No. 3826.

Fuchs, Victor (1989), "Women's Quest for Economic Equality," Journal of Economic Perspectives, 3(1), 25-41.

Grubb, W. N. and R. H. Wilson (1989), "Sources of Increasing Inequality in Wages and Salaries, 1960-80," Monthly Labor Review, 112(4), 3-14.

Harrison, Bennett, Chris Tilly, and Barry Bluestone (1986), "The Great U-Turn: Increasing Inequality in Wage and Salary Income in the U.S.," study prepared for the U.S. Congressional Joint Economic Committee.

Heckman, James and Jose Scheinkman (1987), "The Importance of Bundling in a GormanLancaster Model of Earnings," Review of Economic Studies, 54(2), 243-255.

Henle, Peter and Paul Ryscavage (1980), "The Distribution of Earned Income among Men and Women," Monthly Labor Review, 103(4), 3-10.

Juhn, Chinhui, Kevin Murphy, and Brooks Pierce (1993), "Wage Inequality and the Rise in the Returns to Skill," Journal of Political Economy, 101(3), 410-442. 
Karoly, Lynn (1990), "The Trend in Inequality among Families, Individuals, and Workers in the United States: A Twenty-Five Year Perspective," paper presented at the Russell Sage Foundation Conference on Causes of Increasing Inequality in the U.S., June 5, 1990.

(1992), "Changes in the Distribution of Individual Earnings in the United States: 1967-1986," Review of Economics and Statistics, 74(1), 107-114.

Katz, Lawrence F. and Lawrence H. Summers (1989), "Industry Rents: Evidence and Implications," Brookings Papers on Economic Activity: Microeconomics, 209-290.

Krueger, Alan B. (1991), "How Computers Have Changed the Wage Structure: Evidence from Microdata, 1984-1989," National Bureau of Economic Research Working Paper No. 3858.

and Lawrence H. Summers (1987), "Reflections on the Inter-Industry Wage Structure," in K. Lang and J. Leonard, eds., Unemployment and the Structure of Labor Markets. London: Basil Blackwell, 17-47.

Kutscher, Ronald and Valerie Personick (1986), "Deindustrialization and the Shift to Services," Monthly Labor Review, 109(6), 3-13.

Levy, Frank and Richard Murnane (1992), "U.S. Earnings Levels and Earnings Inequality: A Review of Recent Trends and Proposed Explanations," Journal of Economic Literature, 30(3), 1333-1381.

Mincer, Jacob (1958), "Investment in Human Capital and Personal Income Distribution," Journal of Political Economy, 66(4), 281-302.

(1974), Schooling, Experience, and Earnings. New York: National Bureau of Economic Research.

Murphy, Kevin and Robert Topel (1987), "Unemployment, Risk, and Earnings: Testing for Equalizing Wage Differences in the Labor Market," in K. Lang and J. Leonard, eds., Unemployment and the Structure of Labor Markets. London: Basil Blackwell, 103-140.

Murphy, Kevin and Finis Welch (1988), "The Structure of Wages," Quarterly Journal of Economics, 107(1), 285-326. and $8(2), 202-229$. (1990), "Empirical Age-Earnings Profiles," Journal of Labor Economics,

Oi, Walter (1962), "Labor as a Quasi-Fixed Factor," Journal of Political Economy, 70(4), 538-555.

O'Neill, June (1990), "The Role of Human Capital in Earnings Differences between Black and White Men," Journal of Economic Perspectives, 4(4), 25-45. 
Plunkert, Lois (1990), "The 1980's: A Decade of Job Growth and Industry Shifts," Monthly Labor Review, 113(9), 3-16.

Shorrocks, Anthony (1982), "Inequality Decompositions by Factor Components," Econometrica, $48,613-625$.

(1984), "Inequality Decompositions by Population Subgroups," Econometrica, 52, 1369-1385.

Smith, James and Michael Ward (1989), "Women in the Labor Market and in the Family," Journal of Economic Perspectives, 3(1), 9-23.

Smith, James and Finis Welch (1979), "Inequality: Race Differences in the Distribution of Earnings," International Economic Review, 20(2), 515-526.

Welch, Finis (1990), "The Employment of Black Men," Journal of Labor Economics, 8(1:2), S26-S74. 


\section{Appendix 1: The Dataset}

The dataset is derived from the March Current Population Surveys (CPS) spanning the years 1973 to 1990 . Every month, the U.S. Census Bureau interviews about 58,000 households (approximately 122,000 persons age 14 and over) as part of the CPS. Each sample is designed to be representative of the civilian, noninstitutional population. The March surveys throughout this period include data on individuals' personal characteristics (age, sex, race, and education) and on their location and employment during the previous year (total wages and salaries, weeks worked, hours worked per week, industry, and occupation). These features have made the March supplement the primary data source used in earnings distribution analyses.

I selected individuals who showed strong attachment to the labor force. The sample includes civilians over age 16 who are not self-employed and who missed no weeks of work due to schooling or retirement. The sample is further limited to workers who reported being in the labor force (working or unemployed) at least 39 weeks and who worked full time (at least 35 hours per week) in the previous year. Though designed to be similar to the sample used by Juhn, Murphy, and Pierce (1993), mine includes both male and female workers of all races in order to paint a more complete picture of the labor market.

Certain adjustments to the earnings data were also necessary. Top-coded data were assigned the truncated mean earnings implied by a Pareto distribution based on the highest reported earnings. Observations with real weekly wages of less than half the 1982 minimum wage for a full-time job were dropped because they are likely to be faulty. Juhn, Murphy, and Pierce show that differences in the imputation techniques used by the Census Bureau can alter wage inequality, but that these differences are largely limited to extremes of the distribution. The biggest switch occurs between 1974 and 1975 and is visible in the decompositions reported here. In order to isolate the conclusions of this paper from the issues that affect the fringes of the distribution, the analysis was also completed with a sample in which the top and bottom 5 percent 
of earners were removed. ${ }^{18}$ There were no differences in the truncated sample analysis that would alter the conclusions of this paper.

The Census Bureau changed its industry codes twice during the sample period. However, the basic structure of the industry coding system was not altered at the two-digit level and could be mapped into consistent two-digit Standard Industry Codes (SIC). I aggregated some of these codes in order to reduce the number of industries to a manageable number (39) and to increase the cell sizes for small industries. The results of this aggregation are shown in table A1. ${ }^{19}$

18 Neither top-coded data nor subminimum wage earnings were ever more than 5 percent of my sample.

19 This aggregation was made on the basis of potential false industry switching seen in matched data. 
Table A1. Industry Classification Scheme

\begin{tabular}{|c|c|c|}
\hline Title & Components & $\begin{array}{l}1987 \text { SIC } \\
\text { codes }\end{array}$ \\
\hline Natural Resources & $\begin{array}{l}\text { Agricultural Production } \\
\text { Agricultural Services } \\
\text { Forestry } \\
\text { Fishing, Hunting, \& Trapping } \\
\text { Mining (Metal, Coal, Oil \& Gas, Minerals) }\end{array}$ & $\begin{array}{c}01,02 \\
07 \\
08 \\
09 \\
10,12,13,14\end{array}$ \\
\hline Construction & Construction (General, Heavy, Special Trade) & $15,16,17$ \\
\hline Food \& Tobacco & $\begin{array}{l}\text { Food \& Kindred Products } \\
\text { Tobacco Products }\end{array}$ & $\begin{array}{l}20 \\
21\end{array}$ \\
\hline Textiles \& Apparel & $\begin{array}{l}\text { Textile Mill Products } \\
\text { Apparel \& Other Textiles }\end{array}$ & $\begin{array}{l}22 \\
23\end{array}$ \\
\hline Wood Products & $\begin{array}{l}\text { Lumber \& Wood Products } \\
\text { Paper \& Allied Products } \\
\end{array}$ & $\begin{array}{l}24 \\
26 \\
\end{array}$ \\
\hline Printing \& Publishing & Printing \& Publishing & 27 \\
\hline Oil Products & $\begin{array}{l}\text { Chemical \& Allied Products } \\
\text { Petroleum \& Coal Products } \\
\text { Rubber \& Misc. Plastic }\end{array}$ & $\begin{array}{l}28 \\
29 \\
30\end{array}$ \\
\hline Light Manufacturing & $\begin{array}{l}\text { Furniture \& Fixtures } \\
\text { Leather } \\
\text { Stone, Clay, \& Glass } \\
\text { Misc. Manufacturing }\end{array}$ & $\begin{array}{l}25 \\
31 \\
32 \\
39\end{array}$ \\
\hline Primary Metals & Primary Metals Industries & 33 \\
\hline Fabricated Metals & Fabricated Metal Products & 34 \\
\hline Industrial Machinery & Industrial Machinery \& Equipment & 35 \\
\hline $\begin{array}{l}\text { Electronics } \\
\text { Instruments }\end{array}$ & $\begin{array}{l}\text { Electronic \& Electrical Equipment } \\
\text { Instruments \& Related Equipment }\end{array}$ & $\begin{array}{l}36 \\
38 \\
\end{array}$ \\
\hline Transportation Equipment & Transportation Equipment & 37 \\
\hline Railroad \& Transit & $\begin{array}{l}\text { Railroad Transportation } \\
\text { Local \& Interurban Passenger Transit }\end{array}$ & $\begin{array}{l}40 \\
41 \\
\end{array}$ \\
\hline Shipping & $\begin{array}{l}\text { Trucking and Warehousing } \\
\text { Water Transportation }\end{array}$ & $\begin{array}{l}42 \\
44 \\
\end{array}$ \\
\hline U.S. Postal Service & U.S. Postal Service & 43 \\
\hline Air Transportation & $\begin{array}{l}\text { Transportation by Air } \\
\text { Transportation Services }\end{array}$ & $\begin{array}{l}45 \\
47 \\
\end{array}$ \\
\hline Communications & Communications & 48 \\
\hline Utilities \& Pipelines & $\begin{array}{l}\text { Pipelines } \\
\text { Electric, Gas, \& Sanitary Utilities }\end{array}$ & $\begin{array}{l}46 \\
49\end{array}$ \\
\hline
\end{tabular}


Table A1 (continued). Industry Classification Scheme

\begin{tabular}{|c|c|c|}
\hline Title & Components & $\begin{array}{l}1987 \text { SIC } \\
\text { codes }\end{array}$ \\
\hline Wholesale--Durables & Wholesale Trade--Durables & 50 \\
\hline Wholesale--Nondurables & Wholesale Trade--Nondurables & 51 \\
\hline Misc. Retail & $\begin{array}{l}\text { Building Materials \& Garden Supplies } \\
\text { Furniture and Home Furnishings Stores } \\
\text { Misc. Retail }\end{array}$ & $\begin{array}{l}52 \\
57 \\
59\end{array}$ \\
\hline Apparel \& General & $\begin{array}{l}\text { Apparel and Accessory Stores } \\
\text { General Merchandise Stores }\end{array}$ & $\begin{array}{l}56 \\
53 \\
\end{array}$ \\
\hline Food Stores & Food Stores & 54 \\
\hline Auto Retail & Auto Dealers \& Service Stations & 55 \\
\hline Eating \& Drinking & Eating \& Drinking Establishments & 58 \\
\hline Money Services & $\begin{array}{l}\text { Depository Institutions } \\
\text { Nondepository Institutions } \\
\text { Security \& Commodity Brokers } \\
\text { Holding \& Other Investment Offices } \\
\end{array}$ & $\begin{array}{l}60 \\
61 \\
62 \\
67 \\
\end{array}$ \\
\hline Insurance & $\begin{array}{l}\text { Insurance Carriers } \\
\text { Insurance Agents, Brokers, \& Service }\end{array}$ & $\begin{array}{l}63 \\
64 \\
\end{array}$ \\
\hline Real Estate & Real Estate & 65 \\
\hline Business Services & Business Services & 73 \\
\hline Repair & $\begin{array}{l}\text { Auto Repair, Services, and Parking } \\
\text { Misc. Repair }\end{array}$ & $\begin{array}{l}75 \\
76\end{array}$ \\
\hline Entertainment \& Hotels & $\begin{array}{l}\text { Motion Pictures } \\
\text { Amusement \& Recreation } \\
\text { Hotels \& Other Lodging Places } \\
\end{array}$ & $\begin{array}{l}78 \\
79 \\
70 \\
\end{array}$ \\
\hline Health Services & Health Services & 80 \\
\hline Professional Services & $\begin{array}{l}\text { Legal Services } \\
\text { Engineering \& Management Services }\end{array}$ & $\begin{array}{l}81 \\
87 \\
\end{array}$ \\
\hline Education & Educational Services & 82 \\
\hline Social Services & $\begin{array}{l}\text { Social Services } \\
\text { Museums } \\
\text { Membership Organizations }\end{array}$ & $\begin{array}{l}83 \\
84 \\
86 \\
\end{array}$ \\
\hline $\begin{array}{l}\text { Personal, Private, \& Misc. } \\
\text { Services }\end{array}$ & $\begin{array}{l}\text { Personal Services } \\
\text { Private Household Services } \\
\text { Services, Not Elsewhere Classified } \\
\end{array}$ & $\begin{array}{l}72 \\
88 \\
89 \\
\end{array}$ \\
\hline Government & Public Administration & 91 to 97 \\
\hline
\end{tabular}


Appendix 2

Equation Estimates for Selected Years

Table A2.1. Standard Wage Equations

\begin{tabular}{|c|c|c|c|c|}
\hline Variable & 1972 & 1979 & 1984 & 1990 \\
\hline Intercept & $\begin{array}{c}5.4034 \\
(0.0103)\end{array}$ & $\begin{array}{c}5.3988 \\
(0.0088)\end{array}$ & $\begin{array}{c}5.2761 \\
(0.0099)\end{array}$ & $\begin{array}{c}5.2462 \\
(0.0102)\end{array}$ \\
\hline EXP & $\begin{array}{c}0.0778 \\
(0.0023)\end{array}$ & $\begin{array}{c}0.0685 \\
(0.0020)\end{array}$ & $\begin{array}{c}0.0731 \\
(0.0022)\end{array}$ & $\begin{array}{c}0.0630 \\
(0.0021)\end{array}$ \\
\hline EXP2 & $\begin{array}{l}-0.0346 \\
(0.0016)\end{array}$ & $\begin{array}{l}-0.0290 \\
(0.0015)\end{array}$ & $\begin{array}{l}-0.0299 \\
(0.0016)\end{array}$ & $\begin{array}{l}-0.0237 \\
(0.0015)\end{array}$ \\
\hline EXP3 & $\begin{array}{c}0.0668 \\
(0.0041)\end{array}$ & $\begin{array}{c}0.0561 \\
(0.0040)\end{array}$ & $\begin{array}{c}0.0561 \\
(0.0043)\end{array}$ & $\begin{array}{c}0.0405 \\
(0.0038)\end{array}$ \\
\hline EXP4 & $\begin{array}{l}-0.0489 \\
(0.0036)\end{array}$ & $\begin{array}{l}-0.0424 \\
(0.0036)\end{array}$ & $\begin{array}{l}-0.0412 \\
(0.0038)\end{array}$ & $\begin{array}{l}-0.0273 \\
(0.0032)\end{array}$ \\
\hline Dropout & $\begin{array}{l}-0.1799 \\
(0.0057)\end{array}$ & $\begin{array}{l}-0.2277 \\
(0.0056)\end{array}$ & $\begin{array}{l}-0.2494 \\
(0.0062)\end{array}$ & $\begin{array}{l}-0.2623 \\
(0.0065)\end{array}$ \\
\hline SomeCol & $\begin{array}{c}0.1328 \\
(0.0068)\end{array}$ & $\begin{array}{c}0.1271 \\
(0.0056)\end{array}$ & $\begin{array}{c}0.1484 \\
(0.0056)\end{array}$ & $\begin{array}{c}0.1783 \\
(0.0054)\end{array}$ \\
\hline ColGrad & $\begin{array}{c}0.4301 \\
(0.0077)\end{array}$ & $\begin{array}{c}0.3885 \\
(0.0065)\end{array}$ & $\begin{array}{c}0.4437 \\
(0.0062)\end{array}$ & $\begin{array}{c}0.4876 \\
(0.0060)\end{array}$ \\
\hline GradSchl & $\begin{array}{c}0.5591 \\
(0.0120)\end{array}$ & $\begin{array}{c}0.5548 \\
(0.0099)\end{array}$ & $\begin{array}{c}0.6472 \\
(0.0090)\end{array}$ & $\begin{array}{c}0.6792 \\
(0.0085)\end{array}$ \\
\hline $\begin{array}{l}\text { White } \\
\text { Female }\end{array}$ & $\begin{array}{l}-0.4602 \\
(0.0056)\end{array}$ & $\begin{array}{l}-0.4079 \\
(0.0049)\end{array}$ & $\begin{array}{l}-0.3440 \\
(0.0048)\end{array}$ & $\begin{array}{l}-0.2835 \\
(0.0047)\end{array}$ \\
\hline $\begin{array}{l}\text { Minority } \\
\text { Female }\end{array}$ & $\begin{array}{l}-0.5236 \\
(0.0114)\end{array}$ & $\begin{array}{l}-0.4438 \\
(0.0094)\end{array}$ & $\begin{array}{l}-0.3925 \\
(0.0089)\end{array}$ & $\begin{array}{l}-0.3320 \\
(0.0086)\end{array}$ \\
\hline \multirow[t]{2}{*}{$\begin{array}{l}\text { Minority } \\
\text { Male }\end{array}$} & $\begin{array}{l}-0.2320 \\
(0.0094)\end{array}$ & $\begin{array}{l}-0.1713 \\
(0.0083)\end{array}$ & $\begin{array}{l}-0.1847 \\
(0.0084)\end{array}$ & $\begin{array}{l}-0.1476 \\
(0.0083)\end{array}$ \\
\hline & $\begin{array}{l}\mathrm{R}^{2}=0.4396 \\
\text { mean }=5.81 \\
\mathrm{n}=38,085\end{array}$ & $\begin{array}{l}\mathrm{R}^{2}=0.4330 \\
\text { mean }=5.77 \\
\mathrm{n}=46,010\end{array}$ & $\begin{array}{c}\mathrm{R}^{2}=0.4146 \\
\text { mean }=5.76 \\
\mathrm{n}=50,132\end{array}$ & $\begin{array}{l}\mathrm{R}^{2}=0.3458 \\
\text { mean }=5.75 \\
\mathrm{n}=51,774\end{array}$ \\
\hline
\end{tabular}

Note: Industry and region dummy variables are included in the regressions, but are not reported. Standard errors are in parentheses. 